Supporting information for

Enantioselective Access to Isoquinuclidines by Tropenone Desymmetrization and Homoallylic Radical Rearrangement: Synthesis of (+)-Ibogamine

David M. Hodgson, , and Jean-Marie Galano

Chemistry Research Laboratory, Department of Chemistry, University of Oxford, Mansfield Road, Oxford OX1 3TA, U.K.

david.hodgson@chem.ox.ac.uk

- Preparative procedures and characterisation data for 4, 7-15, and (+)-1.

- Copies of ${ }^{1} \mathrm{H}$ and ${ }^{13} \mathrm{C}$ NMR spectra of 4, 8-15, and (+)-1.

\title{
General Details
}

All reactions requiring anhydrous conditions were conducted in flame-dried apparatus under an atmosphere of argon. Syringes and needles for the transfer of reagents were dried at $140{ }^{\circ} \mathrm{C}$ and allowed to cool in a desiccator over $\mathrm{P}_{2} \mathrm{O}_{5}$ before use. THF was distilled from benzophenone ketyl; DMSO and $\mathrm{NEt}_{3}$ from $\mathrm{CaH}_{2} ; \mathrm{MeOH}$ from $\mathrm{Mg}(\mathrm{OMe})_{2}$; benzene, $\mathrm{MeCN}$, and $\mathrm{CH}_{2} \mathrm{Cl}_{2}$ by passing through basic alumina. Air was dried by passing through $\mathrm{CaCl}_{2}$. Reactions were monitored by TLC, using plates pre-coated with a $0.25 \mathrm{~mm}$ layer of silica containing a fluorescent indicator. Visualization of reaction components was achieved with $254 \mathrm{~nm}$, and with a basic $\mathrm{KMnO}_{4}$ dip. Organic layers were dried using $\mathrm{MgSO}_{4}$ unless otherwise stated. Column chromatography was carried out on Kieselgel $60(40-63 \mu \mathrm{m})$. Petroleum ether refers to the fraction of petroleum boiling between $30{ }^{\circ} \mathrm{C}$ and $40{ }^{\circ} \mathrm{C}$. IR spectra were recorded as either $\mathrm{KBr}$ discs or thin films. Melting points were recorded on a Kofler hot block, and are uncorrected. ${ }^{1} \mathrm{H}$ and ${ }^{13} \mathrm{C}$ NMR spectra of compounds were recorded in $\mathrm{CDCl}_{3}$ at $25{ }^{\circ} \mathrm{C}$ unless otherwise stated. Chemical shifts are reported relative to $\mathrm{CDCl}_{3}\left(\delta_{\mathrm{H}} 7.25\right)$ and $\mathrm{CHCl}_{3}\left(\delta_{\mathrm{C}}(\right.$ central line of $\left.\mathrm{t}) 77.23\right)$ unless otherwise stated. Coupling constants $(J)$ are given in $\mathrm{Hz}$, multiplicities are given as multiplet $(\mathrm{m})$, singlet $(\mathrm{s})$, doublet $(\mathrm{d})$, triplet $(\mathrm{t})$, or quartet (q). COSY, HMQC, HMBC, and DEPT experiments were use to aid spectral assignments. Doubling of signals due to Boc rotamers was often observed: in these cases the word 'and' is used specifically to signify extra peaks and coupling constants arising from rotamers in the spectra. 


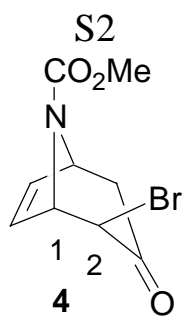

Preparation of and data for $\alpha$-bromoketone $4^{1}$

To a stirred solution of the chiral lithium amide $6^{2}$ in THF $(25 \mathrm{~mL})$ [prepared from the corresponding amine (3.26 g, $12.5 \mathrm{mmol})$ and $n$-BuLi $(2.5 \mathrm{M}$ in hexane; $5.0 \mathrm{~mL}, 12.5 \mathrm{mmol})$ at $-78{ }^{\circ} \mathrm{C}$ ] was added HMPA $(2.9 \mathrm{~mL}, 16.6 \mathrm{mmol})$ at $-78{ }^{\circ} \mathrm{C}$, and the resulting mixture was warmed to room temperature for $1 \mathrm{~h}$; it was then cooled to $-90{ }^{\circ} \mathrm{C}$. To the cooled mixture were added $\mathrm{Me}_{3} \mathrm{SiCl}(3.2 \mathrm{~mL}, 25.2 \mathrm{mmol})$ and then tropenone $3^{3}(1.5 \mathrm{~g}, 8.3 \mathrm{mmol})$ in $\mathrm{THF}(10 \mathrm{~mL})$ at $-90{ }^{\circ} \mathrm{C}$ over $20 \mathrm{~min}$; the reaction mixture was then stirred for $2 \mathrm{~h}$ at $-90{ }^{\circ} \mathrm{C}$. The reaction was quenched by the addition of saturated $\mathrm{NaHCO}_{3}(30 \mathrm{~mL})$ to the mixture, after which the aqueous layer was separated and extracted with $\mathrm{Et}_{2} \mathrm{O}(3 \times 15 \mathrm{~mL})$. To the combined organic extracts were added cold dilute $\mathrm{HCl}$ solution $(0.2 \mathrm{M}, 20 \mathrm{~mL})$, after which the aqueous layer was separated and the process repeated once.The remaining organic extract was then washed with saturated aq. $\mathrm{NaHCO}_{3}(10 \mathrm{~mL})$ and with brine $(10 \mathrm{~mL})$, then dried and evaporated to give the corresponding silylenol ether 7 as a pale yellow oil which was used in the next step without further purification. Basification of the remaining acidic aqueous layer $(\mathrm{NaOH}$ pellets) followed by extraction with ether $(3 \times 15 \mathrm{~mL})$ and further purification by Kugelrohr distillation (bp $120^{\circ} \mathrm{C} / 0.8 \mathrm{mmHg}$ ) gave recovered chiral amine $(2.9 \mathrm{~g}, \sim 90 \%)$.

To a stirred solution of silylenol ether 7 in THF $(20 \mathrm{~mL})$ at $0{ }^{\circ} \mathrm{C}$ was added recrystallized NBS $(1.63 \mathrm{~g}, 9.16 \mathrm{mmol})$ in one portion. The resulting solution was stirred at $0{ }^{\circ} \mathrm{C}$ for $10 \mathrm{~min}$ and then saturated aq. $\mathrm{NH}_{4} \mathrm{Cl}(30 \mathrm{~mL})$ and ether $(30 \mathrm{~mL})$ were added. The two layers were separated and the aqueous layer was extracted with ether $(2 \times 25 \mathrm{~mL})$. The combined organic layers were washed with brine $(20 \mathrm{~mL})$, dried, concentrated in vacuo, and purified by column chromatography on silica with petroleum ether-EtOAc (8-2) as eluent to give a single diastereoisomer of $\alpha$-bromoketone (+)-4 $(1.73 \mathrm{~g}, 80 \%, 80 \%$ ee $)$ as a white solid. (+)-4 was recrystallized twice from ether-petroleum ether to provide bromoketone 4 of >99\% ee (969 mg, 45\% yield from 4) according to chiral GC analysis; $R_{\mathrm{f}} 0.36\left(\mathrm{Et}_{2} \mathrm{O}\right) ; \operatorname{mp} 29-30{ }^{\circ} \mathrm{C} ;[\alpha]_{\mathrm{D}}^{22}+256.7\left(c 1, \mathrm{CHCl}_{3}\right)$ of a sample of $>99 \%$ ee; $v_{\max }(\mathrm{KBr}) / \mathrm{cm}^{-1}$ $3087,2958,1715,1455,1403,1329,1279,1119,986,730 ; \delta_{\mathrm{H}}\left(400 \mathrm{MHz}, \mathrm{CDCl}_{3}\right)$ : $6.38(1 \mathrm{H}$, br s, $\mathrm{C} H=), 6.20(1 \mathrm{H}$, br s, $\mathrm{CH}=), 5.14$ and $5.03(1 \mathrm{H}$, br s, $\mathrm{C} H \mathrm{~N}), 4.95(1 \mathrm{H}$, br s, $\mathrm{CHN}), 4.00(1 \mathrm{H}$, br s, $\mathrm{C}(2) \mathrm{H}), 3.71(3 \mathrm{H}, \mathrm{s}, \mathrm{OMe}), 3.09\left(1 \mathrm{H}, \mathrm{br} \mathrm{d}, J 16, \mathrm{C}(4) \mathrm{H}^{\text {exo }}\right), 2.35\left(1 \mathrm{H}, \mathrm{d}, J 16, \mathrm{C}(4) \mathrm{H}^{\text {endo }}\right), \delta_{\mathrm{C}}(100$ $\mathrm{MHz}) 198.7(\mathrm{C}=\mathrm{O}), 153.5\left(\mathrm{NCO}_{2}\right), 137.9$ and $137.4(\mathrm{CH}=), 131.7$ and $131.2(\mathrm{CH}=), 61.5(C \mathrm{HN})$, 56.3 and $56.1(\mathrm{CHN}), 52.6(\mathrm{OMe}), 48.3(\mathrm{C} 2), 43.1$ and $42.8(\mathrm{C} 4) ; \mathrm{m} / \mathrm{z}\left(\mathrm{CI}^{+}\right), 279$ and 277 $\left(\mathrm{M}+\mathrm{NH}_{4}{ }^{+}, 100 \%\right),\left(\right.$ Found $\left(\mathrm{ES}^{+}\right) \mathrm{M}+\mathrm{NH}_{4}{ }^{+}, 277.0184 . \mathrm{C}_{9} \mathrm{H}_{14} \mathrm{BrN}_{2} \mathrm{O}_{3}$ requires 277.0182). 
GC analysis of 4 for ee determination: (CP Chirasil Dex-CD column using $\mathrm{H}_{2}$ as a carrier flow). Program $100{ }^{\circ} \mathrm{C}$ to $160{ }^{\circ} \mathrm{C}$ at a rate of $0.5{ }^{\circ} \mathrm{C} / \mathrm{min}, 1 \mathrm{~mL} / \mathrm{min}, 3 \mathrm{mg} / \mathrm{mL}$ ), $\mathrm{t}_{\mathrm{r}} \mathrm{min}=115.1 \mathrm{~min}$ and $\mathrm{t}_{\mathrm{r}} \mathrm{maj}=115.8 \mathrm{~min}$.

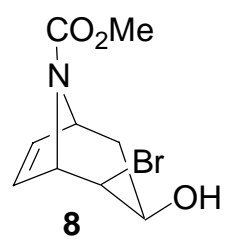

\section{Preparation of and data for bromohydrin $8^{4}$}

To a cold $\left(-30{ }^{\circ} \mathrm{C}\right)$, stirred solution of $\alpha$-bromoketone $(+)-4 \quad(900 \mathrm{mg}, 3.46 \mathrm{mmol}$, >99\% ee) in $20 \mathrm{~mL}$ of 1:1 MeOH-THF was added $\mathrm{NaBH}_{4}(197 \mathrm{mg}, 5.19 \mathrm{mmol})$ in one portion. The reaction mixture was allowed to slowly warm up to room temperature over a period of $2 \mathrm{~h}$ [the reduction being sluggish from $-30{ }^{\circ} \mathrm{C}$ to $-15{ }^{\circ} \mathrm{C}$; careful control of the temperature must be performed from $-15{ }^{\circ} \mathrm{C}$ to $0{ }^{\circ} \mathrm{C}$ (where most of the reduction occurs) to avoid competitive reduction at $\mathrm{C} 2$ ]. The reaction mixture was then quenched with dilute aqueous $\mathrm{HCl}(1 \mathrm{M})$ until gas evolution ceased, then further diluted with EtOAc $(20 \mathrm{~mL})$. The two layers were separated and the aqueous layer was extracted with EtOAc $(4 \times 25 \mathrm{~mL})$. The combined organic layers were washed with saturated aq. $\mathrm{NaHCO}_{3}(10 \mathrm{~mL})$, dried, concentrated in vacuo, and purified by column chromatography on silica with petroleum ether-EtOAc (1-1) as eluent to give a single diastereoisomer of bromohydrin (+)-8 (508 $\mathrm{mg}, 56 \%)$ as a viscous oil, which crystallized to a white solid on standing; $R_{\mathrm{f}} 0.33$ (EtOAc); mp 56-58 ${ }^{\circ} \mathrm{C} ;[\alpha]_{\mathrm{D}}^{22}+45.4\left(c 0.5, \mathrm{CHCl}_{3}\right), v_{\max }(\mathrm{KBr}) / \mathrm{cm}^{-1} 3418,3080,2995,2927,2854$, $1695,1455,1109,1006,694, \delta_{\mathrm{H}}\left(400 \mathrm{MHz}, \mathrm{CDCl}_{3}\right)$ : 6.20-6.15 $(2 \mathrm{H}, \mathrm{m}, \mathrm{CH}=), 5.14$ and $5.02(1 \mathrm{H}, \mathrm{br}$ s, CHN), 4.82 and $4.77(1 \mathrm{H}$, br s, CHN $), 4.43-4.40(1 \mathrm{H}, \mathrm{m}, \mathrm{C}(2) \mathrm{H}), 3.85-3.80(1 \mathrm{H}, \mathrm{m}, \mathrm{C}(3) \mathrm{H}), 3.70$ $(3 \mathrm{H}, \mathrm{s}, \mathrm{OMe}), 2.09(1 \mathrm{H}$, br s, OH), 1.85-1.80 (1H, br dd, $J 13$ and 6, C(4)H), 1.67-1.62 (1H, m, $\mathrm{C}(4) \mathrm{H}), \delta_{\mathrm{C}}(100 \mathrm{MHz}) 153.8\left(\mathrm{NCO}_{2}\right), 134.9$ and $134.1(\mathrm{CH}=), 130.5$ and $129.7(\mathrm{CH}=), 64.5$ $(\mathrm{CHOH}), 62.8(\mathrm{CHN}), 57.8(\mathrm{C} 2), 57.2$ and $56.8(\mathrm{CHN}), 52.5$ and $52.4(\mathrm{OMe}), 31.3$ and $31.1(\mathrm{C} 4)$; $m / z\left(\mathrm{CI}^{+}\right), 281$ and $279\left(\mathrm{M}+\mathrm{NH}_{4}^{+}, 100 \%\right)$, (Found $\left(\mathrm{ES}^{+}\right) \mathrm{M}+\mathrm{NH}_{4}^{+}, 279.0337 . \mathrm{C}_{9} \mathrm{H}_{16} \mathrm{BrN}_{2} \mathrm{O}_{3}$ requires 279.0339). 


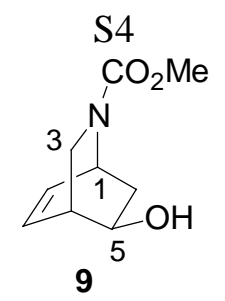

\section{Preparation of and data for dehydroisoquinuclidinol 9 from bromohydrin 8 (stochiometric version)}

A solution of bromohydrin (+)-8 $(50 \mathrm{mg}, 0.19 \mathrm{mmol})$ in toluene $(5 \mathrm{~mL})$ was stirred and heated under argon at $90{ }^{\circ} \mathrm{C}$, and a solution of $\mathrm{Bu}_{3} \mathrm{SnH}(43 \mu \mathrm{L}, 0.23 \mathrm{mmol})$ and $\mathrm{AIBN}(1.6 \mathrm{mg}, 5 \%)$ in toluene $(5 \mathrm{~mL})$ was added over $1 \mathrm{~h}$ via syringe pump. After a further $15 \mathrm{~min}$, TLC analysis showed complete consumption of the starting material. The reaction mixture was cooled, washed with saturated aq. $\mathrm{NaHCO}_{3}(10 \mathrm{~mL})$ and extracted with EtOAc $(10 \mathrm{~mL})$. The two layers were separated and the aqueous layer was extracted with EtOAc $(3 \times 10 \mathrm{~mL})$. The combined organic layers were washed with brine $(10 \mathrm{~mL})$, dried, concentrated in vacuo, and purified by column chromatography on silica with petroleum ether-EtOAc (6-4) as eluent to give dehydroisoquinuclidinol (-)-9 (26 mg, 75\%) as a colorless oil; $R_{\mathrm{f}} 0.25$ (EtOAc); $[\alpha]_{\mathrm{D}}^{22}-125.4$ (c 0.5, $\left.\mathrm{CHCl}_{3}\right), v_{\max }\left(\right.$ neat) $/ \mathrm{cm}^{-1} 3418,3056,2958$, 2980, 1682; 1455, 1398, 1192, 1120, 1084, 768, 715, $\delta_{\mathrm{H}}\left(400 \mathrm{MHz}, \mathrm{CDCl}_{3}\right): 6.45-6.31(2 \mathrm{H}, \mathrm{m}$, $\mathrm{CH}=), 4.73$ and $4.58(1 \mathrm{H}$, br s, $\mathrm{C}(1) \mathrm{H}), 3.99-3.97(1 \mathrm{H}, \mathrm{m}, \mathrm{C}(5) \mathrm{H}), 3.83-3.78(1 \mathrm{H}, \mathrm{m}, \mathrm{C}(3) \mathrm{H}), 3.68$ and $3.67(3 \mathrm{H}, \mathrm{s}, \mathrm{OMe}), 2.92$ and $2.87(1 \mathrm{H}, \mathrm{d}, J 10, \mathrm{C}(3) \mathrm{H}), 2.78-2.73(1 \mathrm{H}, \mathrm{m}, \mathrm{C}(4) \mathrm{H}), 2.31(1 \mathrm{H}$, br s, OH), 2.00-1.89 (1H, m, C(6)H), 1.64-1.55 (1H, m, C(6)H), $\delta_{\mathrm{C}}(100 \mathrm{MHz}) 155.8\left(\mathrm{NCO}_{2}\right), 134.0$ and $133.4(\mathrm{CH}=), 132.5$ and $132.1(\mathrm{CH}=), 65.2(\mathrm{C} 5), 52.3(\mathrm{OMe}), 46.4$ and $45.9(\mathrm{C} 1), 40.3$ and 40.1 (C3), 38.4 and $38.3(\mathrm{C} 4), 36.9(\mathrm{C} 6) ; \mathrm{m} / z\left(\mathrm{CI}^{+}\right), 201\left(\mathrm{M}+\mathrm{NH}_{4}{ }^{+}, 65 \%\right), 184\left(\mathrm{M}+\mathrm{H}^{+}, 100\right)$, (Found $\left(\mathrm{ES}^{+}\right) \mathrm{M}+\mathrm{H}^{+}, 184.0970 . \mathrm{C}_{9} \mathrm{H}_{14} \mathrm{NO}_{3}$ requires 184.0968).

\section{Preparation of dehydroisoquinuclidinol 9 from bromohydrin 8 (catalytic version)}

To a stirred solution of (+)-8 (400 mg, $1.53 \mathrm{mmol})$ in $10 \mathrm{~mL}$ of EtOH was added $\mathrm{NaBH}_{4}(87 \mathrm{mg}$, $2.30 \mathrm{mmol}$ ), $\mathrm{AIBN}(25 \mathrm{mg}, 0.15 \mathrm{mmol})$, and $\mathrm{Bu}_{3} \mathrm{SnCl}(62 \mu \mathrm{L} ; 0.23 \mathrm{mmol})$ (effervescence occurred for $2 \mathrm{~min}$ ) and the suspension was then heated to reflux for $30 \mathrm{~min}$ (ending of effervescence marked completion of the rearrangement). The suspension produced was evaporated under reduced pressure, and then diluted with EtOAc $(20 \mathrm{~mL})$ and quenched with aq. $\mathrm{HCl}(1 \mathrm{M}, 5 \mathrm{~mL})$. The two layers were separated and the aqueous layer was further extracted with EtOAc $(2 \times 20 \mathrm{~mL})$. The combined organic layers were washed with brine $(10 \mathrm{~mL})$, dried, concentrated in vacuo, and purified by column chromatography on silica with petroleum ether-EtOAc (6-4) as eluent to give dehydroisoquinuclidinol (-)-9 (230 mg, 82\%). 
Preparation of dehydroisoquinuclidinol 9 from $\alpha$-bromoketone 4 (one pot)

To a cold $\left(-30{ }^{\circ} \mathrm{C}\right)$, stirred solution of $(+)-4(900 \mathrm{mg}, 3.47 \mathrm{mmol},>99 \%$ ee) in EtOH (20 mL) was added $\mathrm{NaBH}_{4}(198 \mathrm{mg}, 5.23 \mathrm{mmol})$ in one portion. The reaction mixture was slowly allowed to warm up to room temperature over a period of $2 \mathrm{~h}$ [the reduction being sluggish from $-30{ }^{\circ} \mathrm{C}$ to $-15{ }^{\circ} \mathrm{C}$; careful control of the temperature must be performed from $-15{ }^{\circ} \mathrm{C}$ to $0{ }^{\circ} \mathrm{C}$ (where most of the reduction occurs) to avoid competitive reduction at C2]. To this reaction mixture was added $\mathrm{NaBH}_{4}(198 \mathrm{mg}, 5.23 \mathrm{mmol})$, AIBN (57 mg, $\left.0.35 \mathrm{mmol}\right)$, and $\mathrm{Bu}_{3} \mathrm{SnCl}(0.141 \mathrm{~mL} ; 0.52 \mathrm{mmol})$ (effervescence occurred for $2 \mathrm{~min}$ ) and the suspension heated to reflux for $30 \mathrm{~min}$ (ending of effervescence marked completion of the rearrangement). The suspension produced was evaporated under reduced pressure, and then diluted with EtOAc $(20 \mathrm{~mL})$ quenched with aqueous $\mathrm{HCl}(1 \mathrm{M}$, $5 \mathrm{~mL})$. The two layers were separated and the aqueous layer was extracted with EtOAc $(2 \times 20 \mathrm{~mL})$. The combined organic layers were washed with brine $(10 \mathrm{~mL})$, dried, concentrated in vacuo, and purified by column chromatography on silica with petroleum ether-EtOAc (6-4) as eluent to give dehydroisoquinuclidinol (-)-9 (515 mg, 81\%).

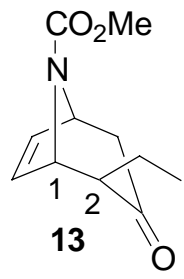

\section{Preparation of and data for $\alpha$-ethylketone 13}

To a stirred solution of the chiral lithium amide $6^{2}$ in THF $(25 \mathrm{~mL})$ [prepared from the corresponding amine $(2.16 \mathrm{~g}, 8.3 \mathrm{mmol})$ and $n$-BuLi $(2.5 \mathrm{M}$ in hexane; $3.33 \mathrm{~mL}, 8.3 \mathrm{mmol})$ at $-78{ }^{\circ} \mathrm{C}$ ] was added HMPA $(1.93 \mathrm{~mL}, 11.1 \mathrm{mmol})$ at $-78{ }^{\circ} \mathrm{C}$, and the resulting mixture was warmed to room temperature for $1 \mathrm{~h}$; it was then cooled to $-90{ }^{\circ} \mathrm{C}$. To the cooled mixture were added $\mathrm{Me}_{3} \mathrm{SiCl}(2.13 \mathrm{~mL}, 16.6 \mathrm{mmol})$ and then tropenone $3^{3}(1.0 \mathrm{~g}, 5.5 \mathrm{mmol})$ in $\mathrm{THF}(7 \mathrm{~mL})$ at $-90{ }^{\circ} \mathrm{C}$ over $20 \mathrm{~min}$; the reaction mixture was then stirred for $2 \mathrm{~h}$ at $-90^{\circ} \mathrm{C}$. The reaction was quenched by the addition of saturated aq. $\mathrm{NaHCO}_{3}(30 \mathrm{~mL})$ to the mixture, after which the aqueous layer was separated and extracted with $\mathrm{Et}_{2} \mathrm{O}(3 \times 15 \mathrm{~mL})$. To the combined organic extracts were added cold dilute $\mathrm{HCl}$ solution $(0.2 \mathrm{M}, 20 \mathrm{~mL})$, after which the aqueous layer was separated and the process repeated once. The remaining organic extract was then washed with saturated aq. $\mathrm{NaHCO}_{3}(10 \mathrm{~mL})$ and with brine $(10 \mathrm{~mL})$, then dried and evaporated to give the corresponding silylenol ether $\mathbf{7}$ as a pale yellow oil which was used in the next step without further purification. Basification of the remaining acidic aqueous layer $(\mathrm{NaOH}$ pellets $)$ followed by extraction with ether $(3 \times 15 \mathrm{~mL})$ and further purification by Kugelrohr distillation (bp $120{ }^{\circ} \mathrm{C} / 0.8 \mathrm{mmHg}$ ) gave recovered chiral amine $(1.98 \mathrm{~g}, \sim 92 \%)$. 
Tetrabutylammonium triphenyldifluorosilicate $(3.0 \mathrm{~g}, 5.5 \mathrm{mmol})$ and activated $4 \AA$ molecular sieves (flame dried for $5 \mathrm{~min}$ ) $(5 \mathrm{~g})$ were placed under nitrogen in a $25 \mathrm{~mL}$ round bottom flask equipped with a septum, to which THF (10 mL ) was added. To the resulting suspension, a solution of the above crude silylenol ether 7 and EtI $(4.43 \mathrm{~mL}, 55.2 \mathrm{mmol})$ was slowly added over $5 \mathrm{~min}$. The mixture was stirred for $30 \mathrm{~min}$ then filtered through a pad of celite and washed with $\mathrm{Et}_{2} \mathrm{O}$. The organic extract was then washed with saturated aq. $\mathrm{NaHCO}_{3}(15 \mathrm{~mL})$ and with brine $(15 \mathrm{~mL})$, then dried and evaporated to give a mixture of $\alpha$-ethylketone $\mathbf{1 3}$ and starting material $\mathbf{3}$ as a yellow oil. Column chromatography on silica with petroleum ether-EtOAc (8-2) as eluent gave $\alpha$-ethylketone $(+)-13$

$(635 \mathrm{mg}, 55 \%, 86 \% \mathrm{brsm})$ and recovered starting material $3(360 \mathrm{mg}) ; R_{\mathrm{f}} 0.40\left(\mathrm{Et}_{2} \mathrm{O}\right) ;[\alpha]_{\mathrm{D}}{ }^{22}+82.4$ (c $1, \mathrm{CHCl}_{3}$ ) of a sample of $80 \%$ ee (determined in the next transformation), $v_{\max }(\mathrm{KBr}) / \mathrm{cm}^{-1} 3081$, 2964, 2937, 2878, 1699, 1455, 1403, 1111, 981, 710; $\delta_{\mathrm{H}}\left(400 \mathrm{MHz}, \mathrm{CDCl}_{3}\right): 6.17$ and $6.15(2 \mathrm{H}$, br s, CH=), 4.89 and $4.84(1 \mathrm{H}$, br s, $\mathrm{CHN}), 4.84$ and $4.75(1 \mathrm{H}$, br s, CHN $), 3.66(3 \mathrm{H}, \mathrm{s}, \mathrm{OMe})$, 2.71-2.56 (1 H, m, C(4)H), 2.23 (1 H, d, J 17, C(4)H), 2.20-2.08 (1 H, m, C(2)H), 1.65-1.49 (2 H, m, $\left.\mathrm{CH}_{2} \mathrm{Me}\right), 0.94\left(3 \mathrm{H}, \mathrm{m}, \mathrm{CH}_{3}\right), \delta_{\mathrm{C}}(100 \mathrm{MHz}) 208.7(\mathrm{C}=\mathrm{O}), 153.8\left(\mathrm{NCO}_{2}\right), 134.5(\mathrm{CH}=), 133.9$ $(\mathrm{CH}=), 58.5(\mathrm{CHN}), 57.8(\mathrm{C} 2), 56.1(\mathrm{CHN}), 52.4(\mathrm{OMe}), 44.6$ and $44.3(\mathrm{C} 4), 23.1\left(\mathrm{CH}_{2}\right), 11.7$ $\left(\mathrm{CH}_{3}\right) ; \mathrm{m} / \mathrm{z}\left(\mathrm{CI}^{+}\right), 227\left(\mathrm{M}+\mathrm{NH}_{4}{ }^{+}, 100 \%\right), 210(75)\left(\right.$ Found $\left(\mathrm{ES}^{+}\right) \mathrm{M}+\mathrm{NH}_{4}{ }^{+}, 227.1387 . \mathrm{C}_{11} \mathrm{H}_{19} \mathrm{~N}_{2} \mathrm{O}_{3}$ requires 227.1390).

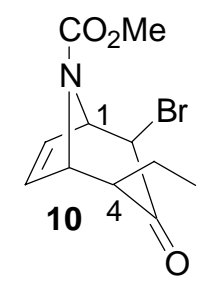

\section{Preparation of and data for $\alpha$-bromoketone 10}

A solution of $n$-BuLi (1.5 M in hexanes, $3.24 \mathrm{~mL}, 4.9 \mathrm{mmol})$ was added dropwise to a solution of $N, N$-diisopropylamine $(0.69 \mathrm{~mL}, 4.9 \mathrm{mmol})$ in THF $(15 \mathrm{~mL})$ at $-78^{\circ} \mathrm{C}$. After $10 \mathrm{~min}$, the solution was removed from the cold bath for $5 \mathrm{~min}$ then recooled to $-78{ }^{\circ} \mathrm{C} . \mathrm{Me}_{3} \mathrm{SiCl}(1.24 \mathrm{~mL}, 9.7 \mathrm{mmol})$ was then added dropwise followed by a solution of $\alpha$-ethylketone (+)-13 (680 $\mathrm{mg}, 3.2 \mathrm{mmol})$ in THF ( $5 \mathrm{~mL})$. After $60 \mathrm{~min}$, the reaction mixture was poured into an aq. solution of $\mathrm{NaHCO}_{3}(20 \mathrm{~mL})$ and extracted with ether $(3 \times 15 \mathrm{~mL})$. The combined organic layers were washed with brine $(20 \mathrm{~mL})$, dried, and evaporated under reduced pressure to give the corresponding crude silylenol ether as a pale yellow oil which was used in the next step without further purification.

To a stirred solution of the above silylenol ether in THF $(7 \mathrm{~mL})$ at $0{ }^{\circ} \mathrm{C}$ was added NBS $(636 \mathrm{mg}$, $3.6 \mathrm{mmol}$ ) in one portion. The resulting solution was stirred at $0{ }^{\circ} \mathrm{C}$ for $10 \mathrm{~min}$ and then poured into a saturated aq. $\mathrm{NH}_{4} \mathrm{Cl}(20 \mathrm{~mL})$ and ether $(20 \mathrm{~mL})$. The two layers were separated and the aqueous 
layer was further extracted with ether $(2 \times 20 \mathrm{~mL})$. The combined organic layers were washed with brine $(15 \mathrm{~mL})$, dried, and evaporated under reduced pressure to give a pale yellow oil. Purification by flash chromatography on silica with petroleum ether-EtOAc (8-2) as eluent gave a single diastereoisomer of $\alpha$-bromoketone (-)-10 (777 $\mathrm{mg}, 83 \%)$ as a white solid. (-)-10 was recrystallized from ether-petroleum ether to provide (-)-10 of $98 \%$ ee $(560 \mathrm{mg}, 60 \%$ yield from 13) according to chiral GC analysis; $R_{\mathrm{f}} 0.41\left(\mathrm{Et}_{2} \mathrm{O}\right) ; \mathrm{mp} 80{ }^{\circ} \mathrm{C}$; $[\alpha]_{\mathrm{D}}{ }^{22}-156.1\left(c 1, \mathrm{CHCl}_{3}\right)$ of a sample of $98 \%$ ee; $V_{\max }($ neat $) / \mathrm{cm}^{-1} 2960,2920,2877,1705,1456,1403,1309,1253,1195,1114,1008,721 ; \delta_{\mathrm{H}}(400$ $\left.\mathrm{MHz}, \mathrm{CDCl}_{3}\right): 6.40$ and 6.36(1 H, br s, $\left.\mathrm{CH}=\right), 6.18$ and $6.16(1 \mathrm{H}$, br s; $\mathrm{CH}=), 5.14$ and $5.04(1 \mathrm{H}$, br s, $\mathrm{CHN}), 4.90$ and $4.83(1 \mathrm{H}$, br s, CHN $), 3.92(1 \mathrm{H}$, br s, C(2)H), $3.73(3 \mathrm{H}, \mathrm{s}, \mathrm{OMe}), 2.33(1 \mathrm{H}$, br s, $\mathrm{C}(4) \mathrm{H}), 1.97-1.85(2 \mathrm{H}, \mathrm{m}, \mathrm{C} 4), 1.00(3 \mathrm{H}, \mathrm{t}, J \mathrm{~T}, \mathrm{CH}) ; \delta_{\mathrm{C}}(100 \mathrm{MHz}) 201.9(C=\mathrm{O}), 154.7\left(\mathrm{NCO}_{2}\right)$, 138.4 and $137.6(\mathrm{CH}=), 131.7$ and $131.0(\mathrm{CH}=), 62.1(\mathrm{CHN}), 59.2$ and $59.0(\mathrm{CHN}), 58.3(\mathrm{C} 4), 52.8$ (OMe), 46.8 (C2), $26.3\left(\mathrm{CH}_{2}\right), 12.1\left(\mathrm{CH}_{3}\right) ; \mathrm{m} / z\left(\mathrm{CI}^{+}\right), 305\left(\mathrm{M}+\mathrm{NH}_{4}{ }^{+}, 100 \%\right), 307$ (90), 289 (50) (Found $\left(\mathrm{ES}^{+}\right) \mathrm{M}+\mathrm{NH}_{4}{ }^{+}, 305.0494 . \mathrm{C}_{11} \mathrm{H}_{18} \mathrm{BrN}_{2} \mathrm{O}_{3}$ requires 305.0495).

GC analysis of (-)-10 for ee determination: (CP Chirasil Dex-CD column using $\mathrm{H}_{2}$ as a carrier flow). Program $70{ }^{\circ} \mathrm{C}$ to $150{ }^{\circ} \mathrm{C}$ at a rate of $0.2{ }^{\circ} \mathrm{C} / \mathrm{min}, 1 \mathrm{~mL} / \mathrm{min}, 3 \mathrm{mg} / \mathrm{mL}$ ), $\mathrm{t}_{\mathrm{r}} \mathrm{min}=225.5 \mathrm{~min}$ and $\mathrm{t}_{\mathrm{r}} \mathrm{maj}$ $=258.0 \mathrm{~min}$.

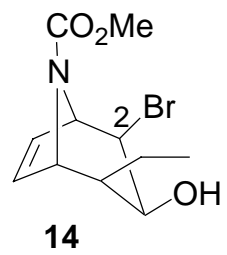

\section{Preparation of and data for bromohydrin $14^{5}$}

To a cold $\left(-30{ }^{\circ} \mathrm{C}\right)$, stirred solution of $\alpha$-bromoketone $10(300 \mathrm{mg}, 1.04 \mathrm{mmol}$, $)$ in $8 \mathrm{~mL}$ of 1:1 MeOH-THF was added $\mathrm{NaBH}_{4}(59 \mathrm{mg}, 1.56 \mathrm{mmol})$ in one portion. The reaction mixture was allowed to slowly warm up to room temperature over a period of $2 \mathrm{~h}$ [the reduction being sluggish from $-30{ }^{\circ} \mathrm{C}$ to $-15{ }^{\circ} \mathrm{C}$; careful control of the temperature must be performed from $-15{ }^{\circ} \mathrm{C}$ to $0{ }^{\circ} \mathrm{C}$ (where most of the reduction occurs) to avoid competitive reduction at $\mathrm{C} 2$ ]. The reaction mixture was then quenched with dilute aqueous $\mathrm{HCl}(1 \mathrm{M})$ until gas evolution ceased, then further diluted with EtOAc $(10 \mathrm{~mL})$. The two layers were separated and the aqueous layer was extracted with EtOAc $(2 \times 15 \mathrm{~mL})$. The combined organic layers were washed with saturated aq. $\mathrm{NaHCO}_{3}(10 \mathrm{~mL})$, dried, concentrated in vacuo, and purified by column chromatography on silica with petroleum ether-EtOAc (6-4) as eluent to give a single diastereoisomer of bromohydrin $\mathbf{1 4}(236 \mathrm{mg}, 78 \%)$ as a white solid; $R_{\mathrm{f}} 0.46$ (EtOAc); mp $93{ }^{\circ} \mathrm{C}$; $\delta_{\mathrm{H}}\left(400 \mathrm{MHz}, \mathrm{CDCl}_{3}\right)$ : 6.22-6.12 (2H, m, CH=), 5.11 and $5.01(1 \mathrm{H}$, br s, CHN), 4.92 and $4.84(1 \mathrm{H}$, br s, $\mathrm{CHN}), 4.34-4.32(1 \mathrm{H}, \mathrm{m}, \mathrm{C}(2) \mathrm{H}), 4.03(1 \mathrm{H}$, br s, 
$\mathrm{C}(3) \mathrm{H}), 3.70(3 \mathrm{H}, \mathrm{s}, \mathrm{OMe}), 2.28(1 \mathrm{H}, \mathrm{br} \mathrm{s}, \mathrm{OH}), 1.78-1.65\left(2 \mathrm{H}, \mathrm{m}, \mathrm{C}(4) \mathrm{H}\right.$ and $\left.\mathrm{CH}_{2}\right), 1.64-1.53(1 \mathrm{H}$, $\left.\mathrm{m}, \mathrm{CH}_{2}\right), 1.05-0.97\left(3 \mathrm{H}, \mathrm{m}, \mathrm{CH}_{3}\right), \delta_{\mathrm{C}}(100 \mathrm{MHz}) 155.1\left(\mathrm{NCO}_{2}\right), 135.3$ and $134.3(\mathrm{CH}=), 130.7$ and $129.8(\mathrm{CH}=), 65.5(\mathrm{C} 3), 63.6$ and $63.5(\mathrm{CHN}), 59.4$ and $59.1(\mathrm{CHN}), 56.4(\mathrm{C} 2), 52.6(\mathrm{OMe}), 42.0$ (C4), $18.5\left(\mathrm{CH}_{2}\right), 12.3$ and $12.1\left(\mathrm{CH}_{3}\right) ; \mathrm{m} / z\left(\mathrm{CI}^{+}\right), 309$ and $307\left(\mathrm{M}+\mathrm{NH}_{4}{ }^{+}, 80 \%\right), 290$ and $292(\mathrm{M}+$ $\left.\mathrm{H}^{+}, 50\right), 227$ (100), (Found $\left(\mathrm{ES}^{+}\right) \mathrm{M}+\mathrm{H}^{+}$, 290.0387. $\mathrm{C}_{11} \mathrm{H}_{17} \mathrm{BrNO}_{3}$ requires 290.0386).

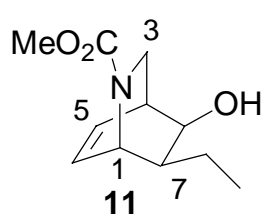

\section{Preparation of and data for dehydroisoquinuclidinol $11^{6}$}

To a cold $\left(-30^{\circ} \mathrm{C}\right)$, stirred solution of $\alpha$-bromoketone $(-)-\mathbf{1 0}(505 \mathrm{mg}, 1.75 \mathrm{mmol}, 98 \%$ ee) in EtOH $(15 \mathrm{~mL})$ was added $\mathrm{NaBH}_{4}(100 \mathrm{mg}, 2.63 \mathrm{mmol})$ in one portion. The reaction mixture was slowly allowed to warm up to room temperature over a period of $2 \mathrm{~h}$ [the reduction being sluggish from $-30{ }^{\circ} \mathrm{C}$ to $-15{ }^{\circ} \mathrm{C}$; careful control of the temperature must be performed from $-15^{\circ} \mathrm{C}$ to $0{ }^{\circ} \mathrm{C}$ (where most of the reduction occurs) to avoid competitive reduction at $\mathrm{C} 2$ ]. To this reaction mixture was added $\mathrm{NaBH}_{4}(100 \mathrm{mg}, 2.63 \mathrm{mmol}), \operatorname{AIBN}(28 \mathrm{mg}, 0.18 \mathrm{mmol})$, and $\mathrm{Bu}_{3} \mathrm{SnCl}(71 \mu \mathrm{L} ; 0.26 \mathrm{mmol})$ (effervescence occurred for $2 \mathrm{~min}$ ) and the suspension heated to reflux for $30 \mathrm{~min}$ (ending of effervescence marked completion of the rearrangement). The suspension produced was evaporated under reduced pressure, and then diluted with EtOAc $(15 \mathrm{~mL})$ quenched with aqueous $\mathrm{HCl}(1 \mathrm{M}$, $5 \mathrm{~mL})$. The two layers were separated and the aqueous layer was extracted with EtOAc $(2 \times 15 \mathrm{~mL})$. The combined organic layers were washed with brine $(10 \mathrm{~mL})$, dried, concentrated in vacuo, and purified by column chromatography on silica with petroleum ether-EtOAc (6-4) as eluent to give dehydroisoquinuclidinol (+)-11 (515 mg, 78\%) as a colorless oil which crystallized upon standing; $R_{\mathrm{f}} 0.25(\mathrm{EtOAc}) ;[\alpha]_{\mathrm{D}}^{22}+77.1\left(c 1, \mathrm{CHCl}_{3}\right), \mathrm{mp} 103{ }^{\circ} \mathrm{C} ; v_{\max } / \mathrm{cm}^{-1} 3442,2958,1682 ; 1456,1398$, $1121,1040,767,702, \delta_{\mathrm{H}}\left(400 \mathrm{MHz}, \mathrm{CDCl}_{3}\right) 6.48$ and $6.42(1 \mathrm{H}$, br dd, $J 8$ and 8, CH=), 6.34 and $6.31(1 \mathrm{H}, \mathrm{br} \mathrm{dd}, J 8$ and 8, CH=), 4.66 and $4.51(1 \mathrm{H}, \mathrm{d}, J 6, \mathrm{C}(1) \mathrm{H}), 3.92(1 \mathrm{H}, \mathrm{m}, \mathrm{C}(8) \mathrm{H}), 3.70(1 \mathrm{H}$, $\mathrm{m}, \mathrm{C} 3(\mathrm{H}), 3.69$ and $3.68(3 \mathrm{H}, \mathrm{s}, \mathrm{OMe}), 2.88$ and $2.82(1 \mathrm{H}, \mathrm{d}, J 11, \mathrm{C}(3) \mathrm{H}), 2.76-2.69(1 \mathrm{H}, \mathrm{m}$, $\mathrm{C}(7) \mathrm{H}), 1.75(1 \mathrm{H}, \mathrm{s}, \mathrm{OH}), 1.66-1.52\left(2 \mathrm{H}, \mathrm{m}, \mathrm{C}(4) \mathrm{H}\right.$ and $\left.\mathrm{CH}_{2}\right), 1.33-1.22\left(1 \mathrm{H}, \mathrm{m}, \mathrm{CH}_{2}\right), 1.02$ and $0.98\left(3 \mathrm{H}, \mathrm{t}, J \mathrm{~J}, \mathrm{CH}_{3}\right) ; \delta_{\mathrm{C}}(100 \mathrm{MHz}) 156.6$ and $156.1\left(\mathrm{NCO}_{2}\right), 135.0$ and $134.3(\mathrm{CH}=), 132.3$ and $131.8(\mathrm{CH}=), 65.2(\mathrm{C} 8), 52.3(\mathrm{OMe}), 48.5$ and $48.0(\mathrm{C} 1), 43.0$ and $42.8(\mathrm{C} 4), 40.3$ and $40.1(\mathrm{C} 3)$, 38.7 and $38.6(\mathrm{C} 7), 19.8$ and $19.7\left(\mathrm{CH}_{2}\right), 12.7$ and $12.4\left(\mathrm{CH}_{3}\right) ; \mathrm{m} / \mathrm{z}\left(\mathrm{CI}^{+}\right), 229(55 \%), 212\left(\mathrm{M}+\mathrm{H}^{+}\right.$, 100), (Found $\left(\mathrm{ES}^{+}\right) \mathrm{M}+\mathrm{H}^{+}, 212.1281 . \mathrm{C}_{11} \mathrm{H}_{18} \mathrm{NO}_{3}$ requires 212.1281). 


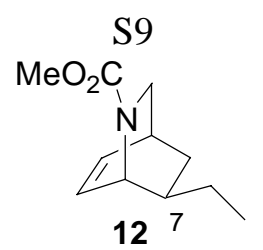

\section{Preparation of and data for dehydroisoquinuclidine 12}

Dehydroisoquinuclidinol (+)-11 (205 mg, $0.97 \mathrm{mmol})$ was added to $\mathrm{KH}(391 \mathrm{mg}$ of a $30 \%$ suspension, $2.92 \mathrm{mmol})$ in $\mathrm{THF}(10 \mathrm{~mL})$ at $0{ }^{\circ} \mathrm{C}$ and the mixture was then stirred at room temperature for $20 \mathrm{~min}$. The mixture was cooled to $0{ }^{\circ} \mathrm{C}$ and $\mathrm{CS}_{2}(175 \mu \mathrm{L}, 2.91 \mathrm{mmol})$ was added and the mixture stirred for $10 \mathrm{~min}$ at $0{ }^{\circ} \mathrm{C}$. Finally, MeI $(181 \mu \mathrm{L}, 2.91 \mathrm{mmol})$ was added and the solution was stirred at room temperature for $20 \mathrm{~min}$. The reaction was quenched with dropwise addition of water until effervescence had ceased and then the aq. layer extracted with $\mathrm{Et}_{2} \mathrm{O}$ $(2 \times 15 \mathrm{~mL})$. The combined extracts were dried, concentrated in vacuo, and purified by column chromatography on silica with petroleum ether- $\mathrm{Et}_{2} \mathrm{O}(8-2)$ as eluent to give the corresponding xanthate

(252 mg, 86\%) as a colorless oil, $R_{\mathrm{f}} 0.52\left(\mathrm{Et}_{2} \mathrm{O}\right)$. The xanthate was not fully characterised, but was identified by a shift in the $\mathrm{CH}-\mathrm{O}$ signal in the ${ }^{1} \mathrm{H}$ NMR spectrum from 3.92 to $5.71 \mathrm{ppm}$ and the appearance of a $3 \mathrm{H}$ singlet at 2.55 and 2.54 (rotamers) assigned to $\mathrm{SCH}_{3}$.

A mixture of xanthate $(250 \mathrm{mg}, 0.83 \mathrm{mmol})$, AIBN (14 mg, $0.08 \mathrm{mmol})$ and $\mathrm{Bu}_{3} \mathrm{SnH}(269 \mu \mathrm{L}$, $1.00 \mathrm{mmol})$, in toluene $(5 \mathrm{~mL})$, was heated at reflux. After $60 \mathrm{~min}$, the reaction mixture was allowed to cool, concentrated in vacuo, and purified by column chromatography on silica with petroleum ether-Et ${ }_{2} \mathrm{O}(8-2)$ as eluent to give dehydroisoquinuclidine (+)-12 (95 mg, 50\% from alcohol (+)-11), $R_{\mathrm{f}} 0.62\left(\mathrm{Et}_{2} \mathrm{O}\right) ;[\alpha]_{\mathrm{D}}^{22}+67.3\left(c 1, \mathrm{CHCl}_{3}\right) ; v_{\max } / \mathrm{cm}^{-1} 3053,2957,2874,1700,1449,1395,1112$, 767, 702, $\delta_{\mathrm{H}}\left(400 \mathrm{MHz}, \mathrm{CDCl}_{3}\right) 6.47$ and $6.42(1 \mathrm{H}$, br dd, $J 8$ and $8, \mathrm{CH}=), 6.34$ and $6.30(1 \mathrm{H}$, br dd, $J 8$ and 8, CH=), 4.59 and $4.44(1 \mathrm{H}, \mathrm{d}, J 6, \mathrm{C}(1) \mathrm{H}), 3.67$ and $3.66(3 \mathrm{H}, \mathrm{s}, \mathrm{OMe}), 3.20(1 \mathrm{H}, \mathrm{td}, J 10$ and 2, $\mathrm{C}(3) \mathrm{H}), 2.98$ and $2.94(1 \mathrm{H}, \mathrm{dt}, J 10$ and 3, $\mathrm{C}(3) \mathrm{H}), 2.70-2.61(1 \mathrm{H}, \mathrm{m}, \mathrm{C}(4) \mathrm{H}), 1.64$ and 1.61 $(1 \mathrm{H}, \mathrm{dt}, J 10$ and $3, \mathrm{C}(8) \mathrm{H}), 1.50-131\left(3 \mathrm{H}, \mathrm{m}, \mathrm{C}(7) \mathrm{H}\right.$ and $\left.\mathrm{CH}_{2}\right), 1.00(1 \mathrm{H}, \mathrm{m}, \mathrm{C}(8) \mathrm{H}), 0.95$ and 0.92 $\left(3 \mathrm{H}, \mathrm{t}, J 7, \mathrm{CH}_{3}\right) ; \delta_{\mathrm{C}}(100 \mathrm{MHz}) 156.7$ and $156.3\left(\mathrm{NCO}_{2}\right), 133.8$ and $133.7(\mathrm{CH}=), 133.3$ and 133.1 $(\mathrm{CH}=), 52.2$ and $52.1(\mathrm{OMe}), 49.1$ and $48.8(\mathrm{C} 1), 48.4$ and $48.1(\mathrm{C} 3), 40.7(\mathrm{C} 4), 30.8$ and $30.6(\mathrm{C} 7)$, $29.9(\mathrm{C} 8), 27.5$ and $27.4\left(\mathrm{CH}_{2}\right), 12.1$ and $12.0\left(\mathrm{CH}_{3}\right) ; \mathrm{m} / z\left(\mathrm{CI}^{+}\right), 196\left(\mathrm{M}+\mathrm{H}^{+}, 100 \%\right)$, (Found $\left(\mathrm{ES}^{+}\right)$ $\mathrm{M}+\mathrm{H}^{+}$, 196.1335. $\mathrm{C}_{11} \mathrm{H}_{18} \mathrm{NO}_{2}$ requires 196.1332).

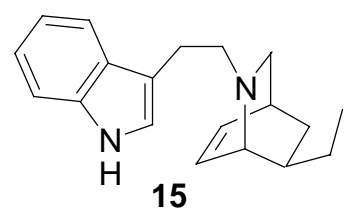

Preparation of and Data for dehydroisoquinuclidine 15 
To a cold $\left(0{ }^{\circ} \mathrm{C}\right)$, stirred solution of dehydroisoquinuclidine (+)-12 (130 mg, $\left.0.67 \mathrm{mmol}\right)$ in $\mathrm{CH}_{2} \mathrm{Cl}_{2}$ $(5 \mathrm{~mL})$ was added $\mathrm{Me}_{3} \mathrm{SiI}(379 \mu \mathrm{L}, 2.67 \mathrm{mmol})$. After $5 \mathrm{~min}$, the mixture was allowed to warm to rt, and left for $3 \mathrm{~h}$. The reaction was then quenched with $\mathrm{MeOH}(2 \mathrm{~mL})$ and concentrated in vacuo to produce the deprotected crude of dehydroisoquinuclidine which was used without purification for the following step.

A suspension of $\mathrm{NaHCO}_{3}(168 \mathrm{mg}, 2.0 \mathrm{mmol})$ in anhydrous $\mathrm{CH}_{3} \mathrm{CN}$ (3 mL) containing the above deprotected isoquinuclidine and tryptophyl bromide (149 $\mathrm{mg}, 0.67 \mathrm{mmol})$ was stirred at reflux for $14 \mathrm{~h}$, then cooled to $25^{\circ} \mathrm{C}$, and poured into water $(5 \mathrm{~mL})$ and extracted with $\mathrm{CHCl}_{3}(3 \times 15 \mathrm{~mL})$. The combined extracts were washed with water, dried, concentrated in vacuo, and purified by column chromatography on silica with $\mathrm{CH}_{2} \mathrm{Cl}_{2}-\mathrm{MeOH}$ (utilising a gradual increase in concentration from 0.5 to $2 \%$ in $\mathrm{MeOH})$ as eluent to give dehydroisoquinuclidine (+)-15 (151 $\mathrm{mg}, 81 \%)$ as a pale brown oil, $R_{\mathrm{f}} 0.41\left(\mathrm{CH}_{2} \mathrm{Cl}_{2}-\mathrm{MeOH}, 4-1\right) ;[\alpha]_{\mathrm{D}}{ }^{22}+9.9\left(c 1, \mathrm{CHCl}_{3}\right) ; v_{\max } / \mathrm{cm}^{-1} 3418,3042,2934$, $1619,1456,1353,1225,1092,741,698 ; \delta_{\mathrm{H}}\left(400 \mathrm{MHz}, \mathrm{CDCl}_{3}\right) 8.04(1 \mathrm{H}, \mathrm{br} \mathrm{s}, \mathrm{NH}), 7.62(1 \mathrm{H}, \mathrm{d}, J 8$, Ar), $7.36(1 \mathrm{H}, \mathrm{d}, J$ 8, Ar), 7.19 (1H, t, J 8, Ar), $7.12(1 \mathrm{H}, \mathrm{d}, J$ 8, Ar), 7.04 (1H, d, J 1, CHNH), 6.40 $(1 \mathrm{H}$, br dd, $J 7$ and $7, \mathrm{CH}=), 6.34(1 \mathrm{H}$, br dd, $J 7$ and $7, \mathrm{CH}=), 3.38(1 \mathrm{H}$, br s, $\mathrm{C}(1) \mathrm{H}), 3.21(1 \mathrm{H}, \mathrm{br} \mathrm{d}$, $J$ 8, C(3)H), 2.99-2.80 (3H, m, benzylic $\mathrm{CH}_{2}$ of indole ring and $1 \mathrm{H}$ of $\mathrm{N}-\mathrm{CH}_{2}$ of tryptophyl group), 2.66-2.56 $\left(1 \mathrm{H}, \mathrm{m}, 1 \mathrm{H}\right.$ of $\mathrm{N}-\mathrm{CH}_{2}$ of tryptophyl group), $2.49(1 \mathrm{H}$, br s, $\mathrm{C}(4) \mathrm{H}), 2.01(1 \mathrm{H}, \mathrm{br} \mathrm{d}, J$, $\mathrm{C}(3) \mathrm{H}), 1.72-1.59\left(2 \mathrm{H}, \mathrm{m}, \mathrm{CH}_{2}\right), 1.56-1.49(1 \mathrm{H}, \mathrm{m}, \mathrm{C}(8) \mathrm{H}), 1.39-1.32(1 \mathrm{H}, \mathrm{m}, \mathrm{C}(7) \mathrm{H}), 0.99(1 \mathrm{H}$, br dd, $J 12$ and 3, C (8)H), $0.94\left(3 \mathrm{H}, \mathrm{t}, J 7, \mathrm{CH}_{3}\right) ; \delta_{\mathrm{C}}(100 \mathrm{MHz}) 136.1$ (quaternary), 133.2 and 132.4 $(\mathrm{CH}=$ ), 127.6 (quaternary), 121.8, 121.7 (indole ring), 119.1, 114.5 (quaternary), 111.1, 58.9 $\left(\mathrm{NCH}_{2}\right), 56.2 \mathrm{C}(3), 55.9 \mathrm{C}(1), 40.1 \mathrm{C}(7), 31.4(\mathrm{C} 4), 29.8(\mathrm{C} 8), 27.2\left(\mathrm{CH}_{2}\right), 24.1\left(\mathrm{CH}_{2}\right.$ benzylic $), 12.6$ $\left(\mathrm{CH}_{3}\right) ; \mathrm{m} / \mathrm{z}\left(\mathrm{CI}^{+}\right), 281\left(\mathrm{M}+\mathrm{H}^{+}, 100 \%\right)$, (Found $\left(\mathrm{ES}^{+}\right) \mathrm{M}+\mathrm{H}^{+}, 281.2016 . \mathrm{C}_{19} \mathrm{H}_{25} \mathrm{~N}_{2}$ requires 281.2012).

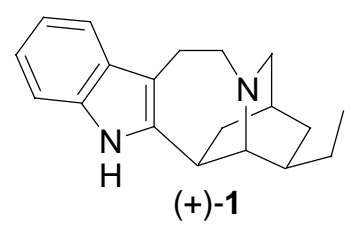

\section{Preparation of and data for (+)-ibogamine 1}

Bis(acetonitrile)palladium chloride $\left(275 \mathrm{mg}, 1.06 \mathrm{mmol}\right.$ ) was slurried in $\mathrm{CH}_{3} \mathrm{CN}(2 \mathrm{~mL})$ and $\mathrm{Et}_{3} \mathrm{~N}$ (74 $\mu \mathrm{L}, 0.53 \mathrm{mmol})$ under an argon atmosphere. Silver tetrafluoroborate (413 $\mathrm{mg}, 2.12 \mathrm{mmol}$ ) was added and the orange heterogeneous mixture immediately became yellow. After $15 \mathrm{~min}$, the dehydroisoquinuclidine (+)-15 (150 $\mathrm{mg}, 0.53 \mathrm{mmol})$ in $\mathrm{CH}_{3} \mathrm{CN}(2.5 \mathrm{~mL})$ was added producing a deep red solution. This mixture was stirred $1 \mathrm{~h}$ at room temperature then heated at $65^{\circ} \mathrm{C}$ for $12 \mathrm{~h}$. The mixture was cooled to $0{ }^{\circ} \mathrm{C}, \mathrm{MeOH}(2 \mathrm{~mL})$ was added, followed by $\mathrm{NaBH}_{4}(20 \mathrm{mg}, 0.53 \mathrm{mmol})$ in portions. The solution was stirred for $1 \mathrm{~h}$ at $0{ }^{\circ} \mathrm{C}$, water $(1 \mathrm{~mL})$ was added and the solution was 
acidified with cold $3 \mathrm{~N}$ aq. $\mathrm{HCl}$. The mixture was filtered through celite to remove palladium black, extracted with ether $(30 \mathrm{~mL})$ then basified with cold concentrated aqueous $\mathrm{NH}_{4} \mathrm{OH}$. The basic aqueous solution was extracted with ethyl acetate $(3 \times 25 \mathrm{~mL})$. The organic extracts were combined, dried, concentrated in vacuo, and purified by column chromatography on silica with $\mathrm{CH}_{2} \mathrm{Cl}_{2}-\mathrm{MeOH}$ (utilising a gradual increase in concentration from 0.5 to $2 \%$ in $\mathrm{MeOH}$ ) as eluent to give ibogamine (+)-1 (37 mg, 25\%) as a pale brown oil, which crystallised upon standing; $R_{\mathrm{f}} 0.51\left(\mathrm{CH}_{2} \mathrm{Cl}_{2}-\mathrm{MeOH}\right.$, 4-1); mp 141-145 ${ }^{\circ} \mathrm{C},[\alpha]_{\mathrm{D}}{ }^{22}+42.2\left(\mathrm{c} 0.29\right.$, EtOH), lit. ${ }^{7}[\alpha]_{\mathrm{D}}{ }^{23}-36.4\left(\mathrm{CHCl}_{3}\right)$, lit. $^{8}[\alpha]_{\mathrm{D}}{ }^{23}-45.8$ $\left(c\right.$ 0.2, EtOH), $v_{\max } / \mathrm{cm}^{-1} 3400, \delta_{\mathrm{H}}\left(400 \mathrm{MHz}, \mathrm{CDCl}_{3}\right) 7.63(1 \mathrm{H}, \mathrm{br} \mathrm{s}), 7.46(1 \mathrm{H}, \mathrm{d}, J 7), 7.36(1 \mathrm{H}, \mathrm{d}$, $J$ 8), 7.25-7.24 (1H, m), 7.12-7.06 (2H, m), 3.42-3.36 (1H, m), 3.34 (1H, ddd, $J 16,12$ and 5), 3.19$3.13(3 \mathrm{H}, \mathrm{m}), 3.08-2.99$ (2H, m), 2.95 (1H, ddd, $J$ 11, 4 and 2), 2.88 (1H, br s), 2.73-2.66 (1H, m), 2.09-2.00 (1H, m), 1.86-1.78 (2H, m), $1.65(2 \mathrm{H}, 2 \mathrm{H}, \mathrm{ddd}, J 13,7$ and 4), 1.61-1.42 $0(2 \mathrm{H}, \mathrm{m}) ; 1.22$ $(1 \mathrm{H}, \mathrm{m}), 0.90(3 \mathrm{H}, \mathrm{t}, J \mathrm{7}), \delta_{\mathrm{C}}(63 \mathrm{MHz}) 141.0,134.7,129.5,121.2,119.3,117.9,110.2,108.9,58.1$, 54.5, 50.0, 41.6, 40.9, 33.8, 31.7, 27.5, 26.1, 20.3, 11.9; $\mathrm{m} / \mathrm{z}\left(\mathrm{CI}^{+}\right), 281\left(\mathrm{M}+\mathrm{H}^{+}, 100 \%\right)$, (Found $\left(\mathrm{ES}^{+}\right) \mathrm{M}+\mathrm{H}^{+}, 281.2010 . \mathrm{C}_{19} \mathrm{H}_{25} \mathrm{~N}_{2}$ requires 281.2012). 


\section{X-ray Data (orteps shown at $40 \%$ probability)}

Methyl (1S,2S,5S)-2-bromo-3-oxo-8-azabicyclo[3.2.1] oct-6-ene-8-carboxylate (4) ${ }^{1}$

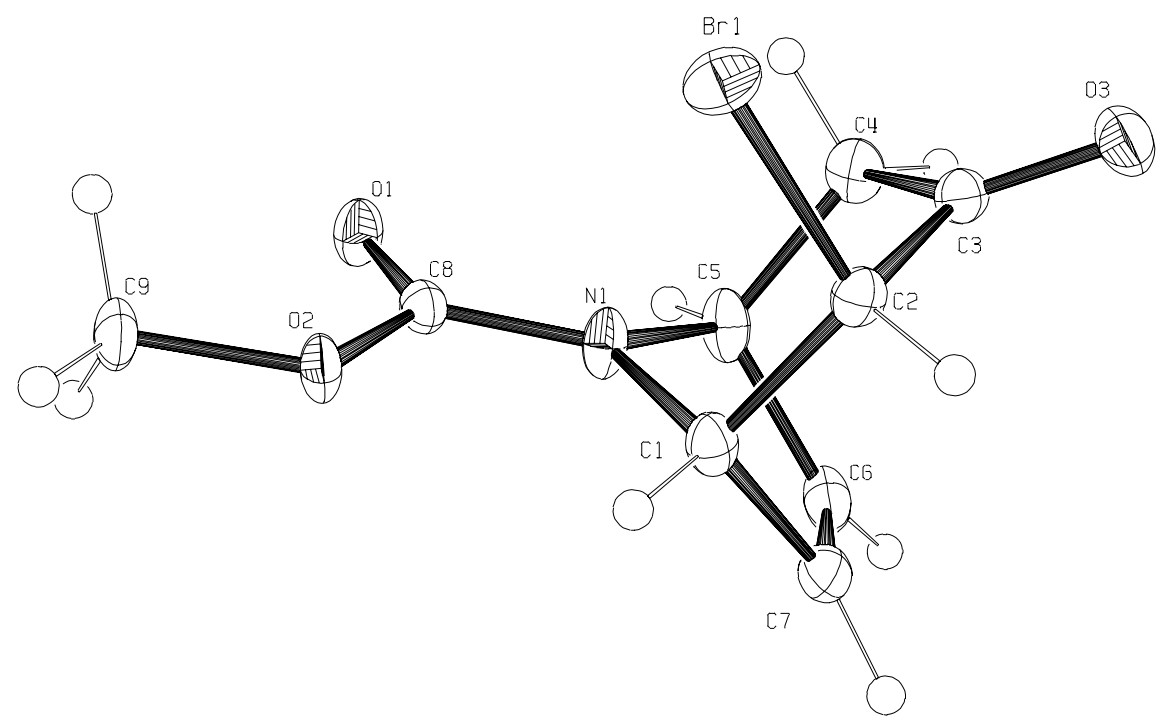

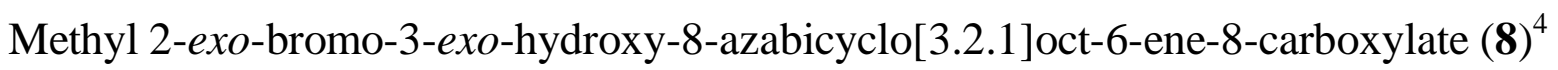

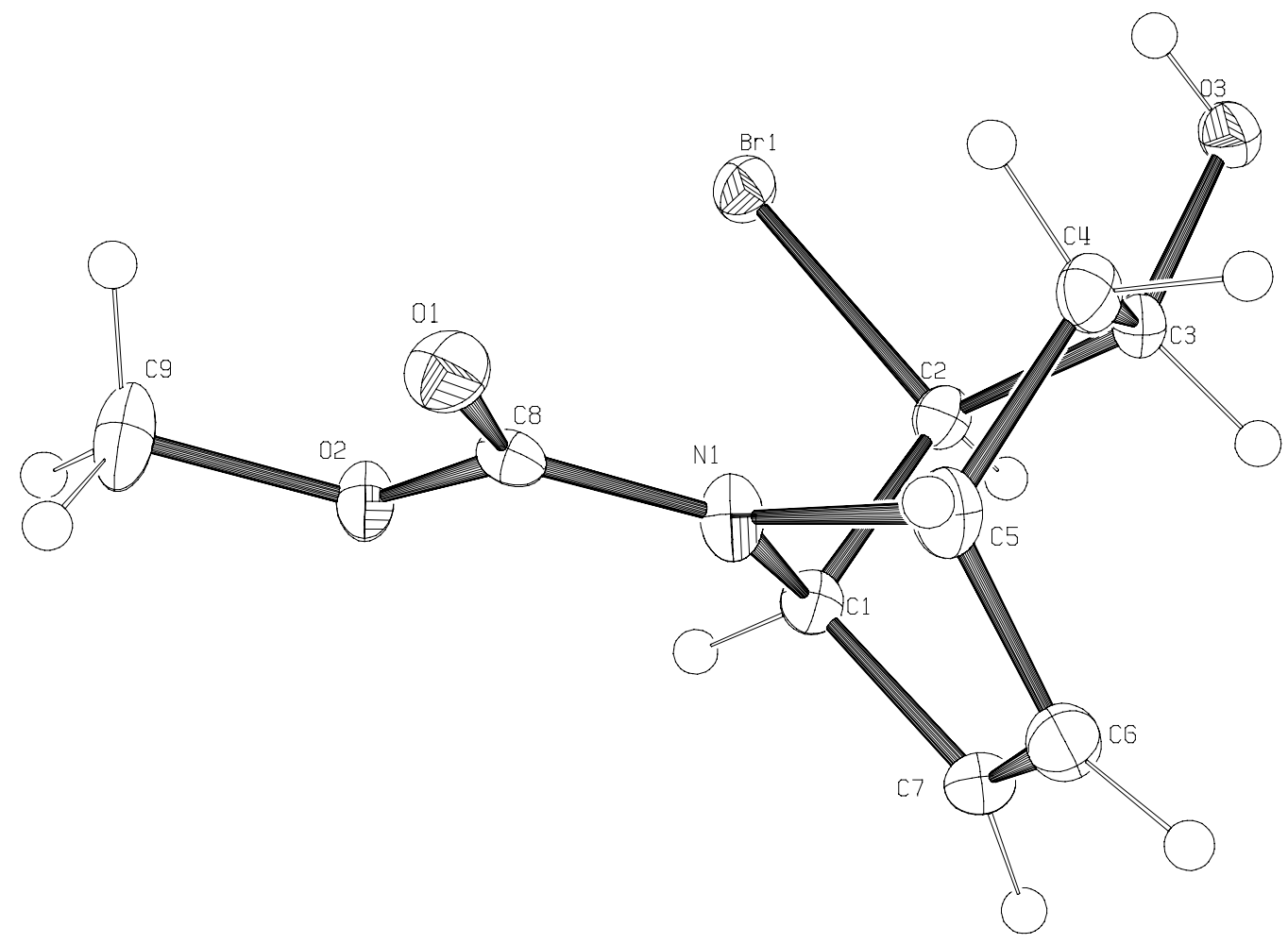


Methyl 2-exo-bromo-4-exo-ethyl-3-exo-hydroxy-8-azabicyclo[3.2.1]oct-6-ene-8carboxylate $(\mathbf{1 4})^{5}$

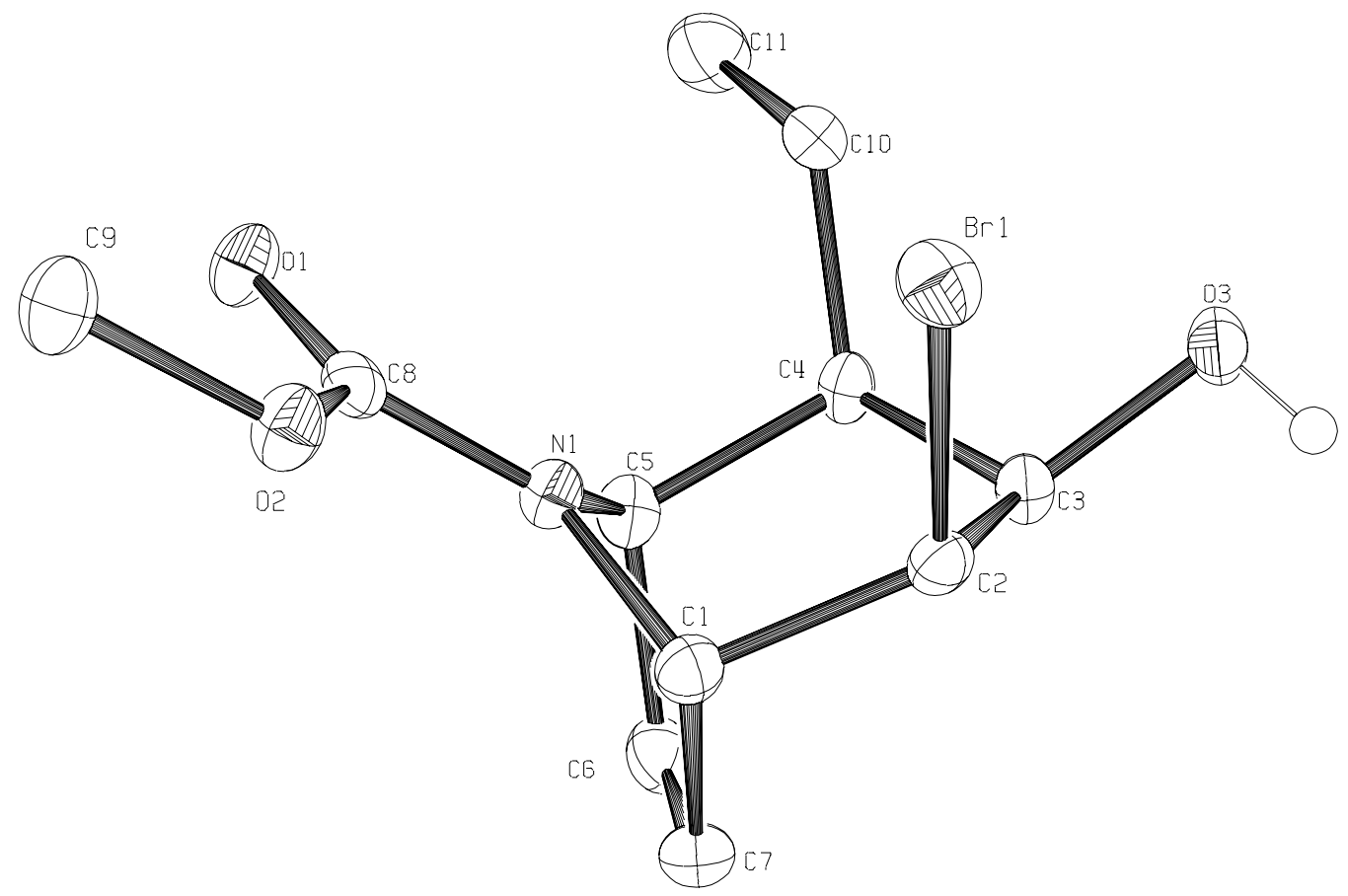

Methyl 7-syn-ethyl-8-syn-hydroxy-2-azabicyclo[2.2.2] oct-5-ene-2-carboxylate (11) ${ }^{6}$

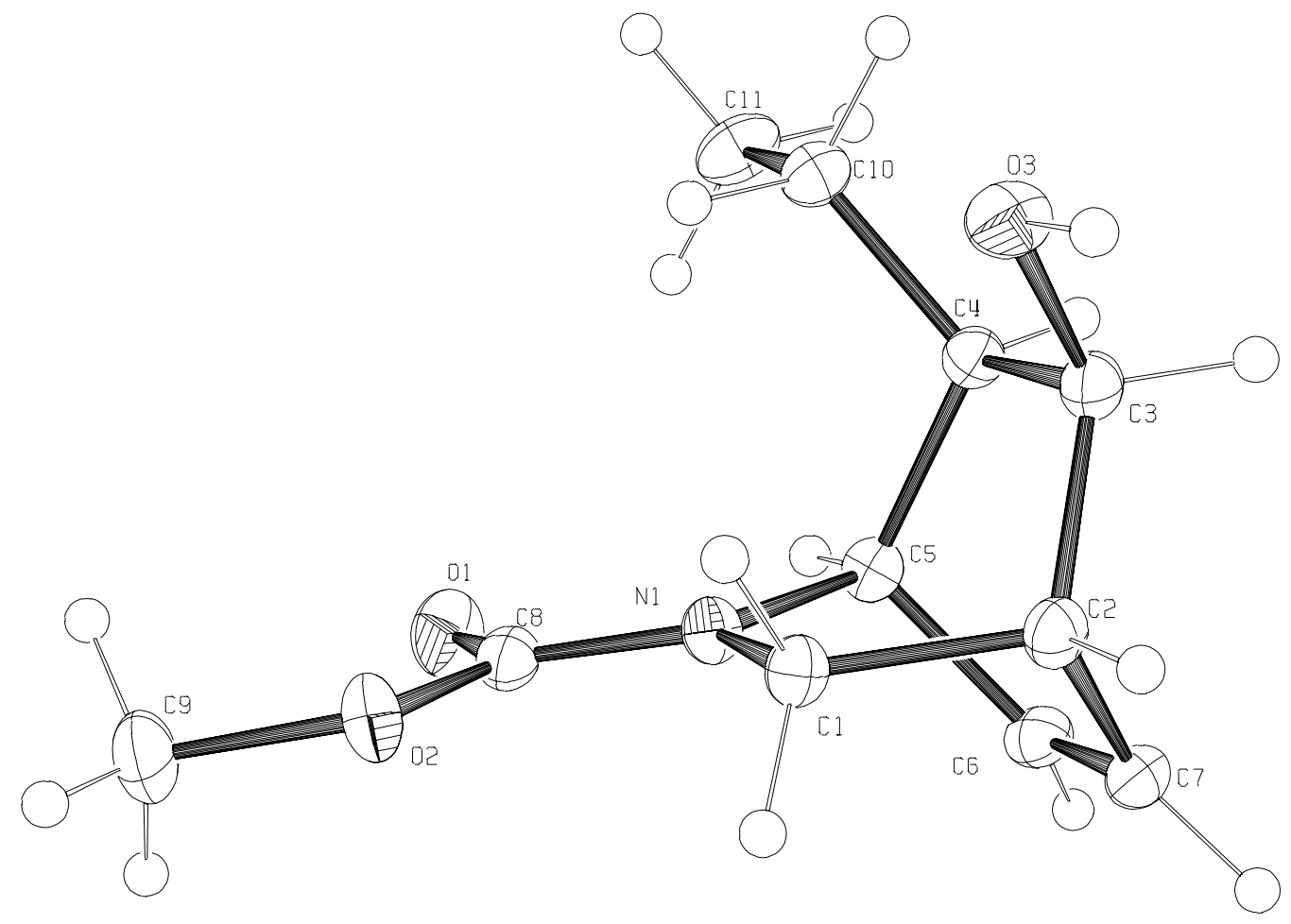




\section{$\underline{\text { References }}$}

1. CDCC 265105 available at http://www.ccdc.cam.ac.uk

2. Curthbertson, E.; O'Brien, P.; Towers, T. D. Synthesis 2001, 693-695.

3. Mann, J.; de Almeida Barbosa, L. C. J. Chem. Soc., Perkin Trans. 1 1992, 787.

4. CDCC 265106 available at http://www.ccdc.cam.ac.uk

5. CDCC 265107 available at http://www.ccdc.cam.ac.uk

6. CDCC 265108 available at http://www.ccdc.cam.ac.uk

7. Dickel, D. F.; Holden, C. L.; Maxfield, R. C.; Paszek, L. E.; Taylor, W. I. J. Am. Chem. Soc. 1958, $80,123-125$

8. White, J. D.; Choi, Y. Helv. Chem. Acta 2002, 85, 4306-4327. 

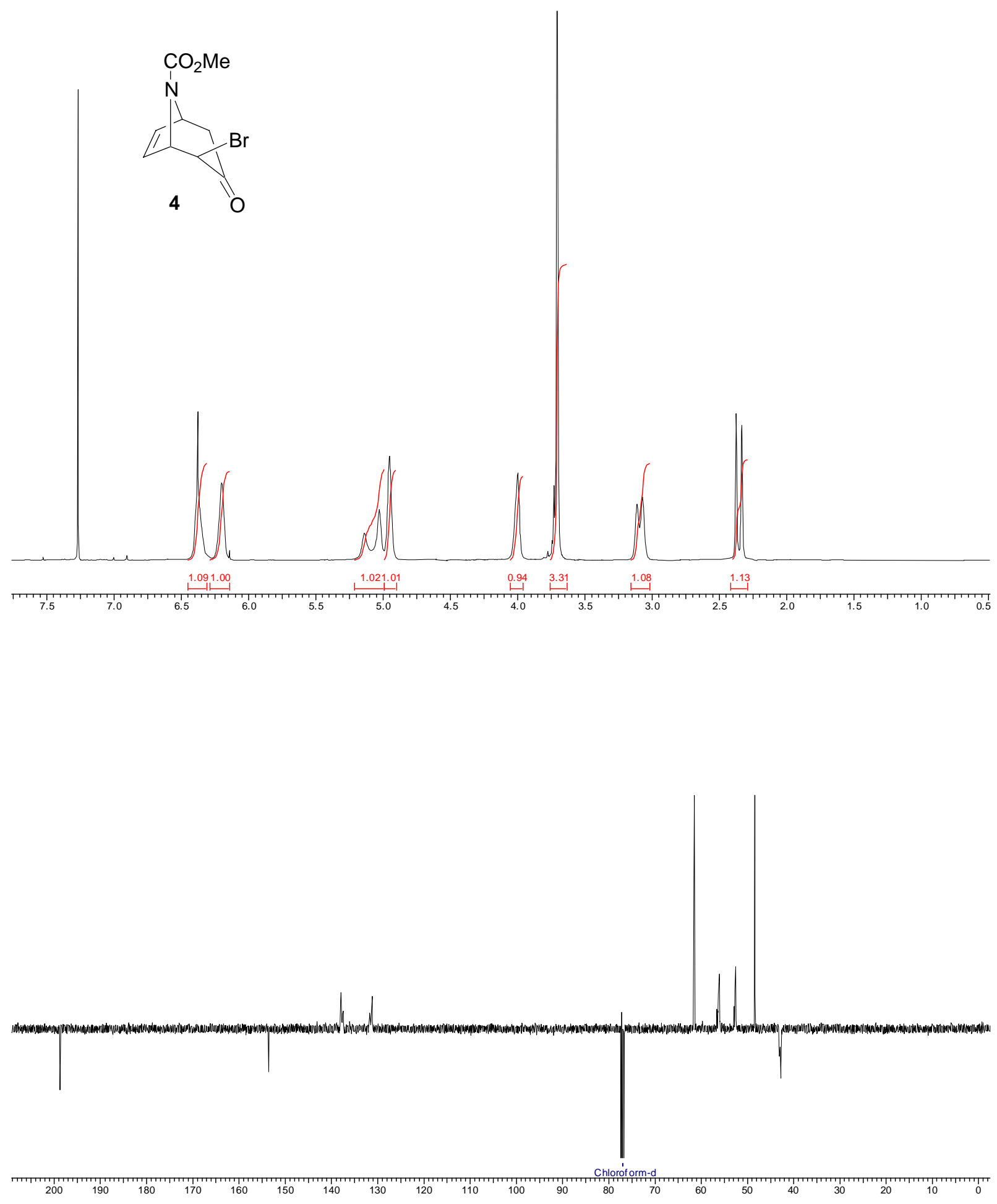

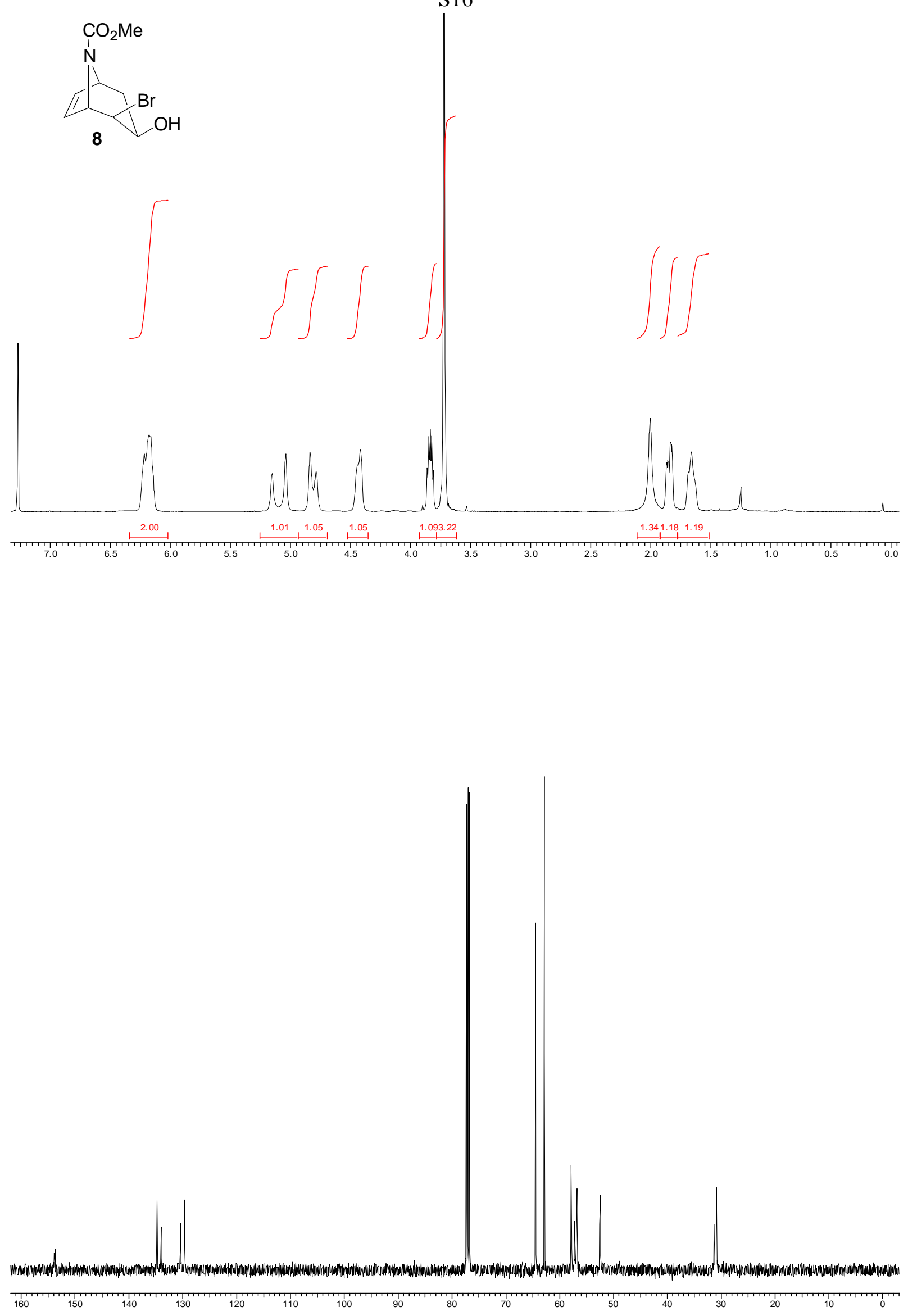

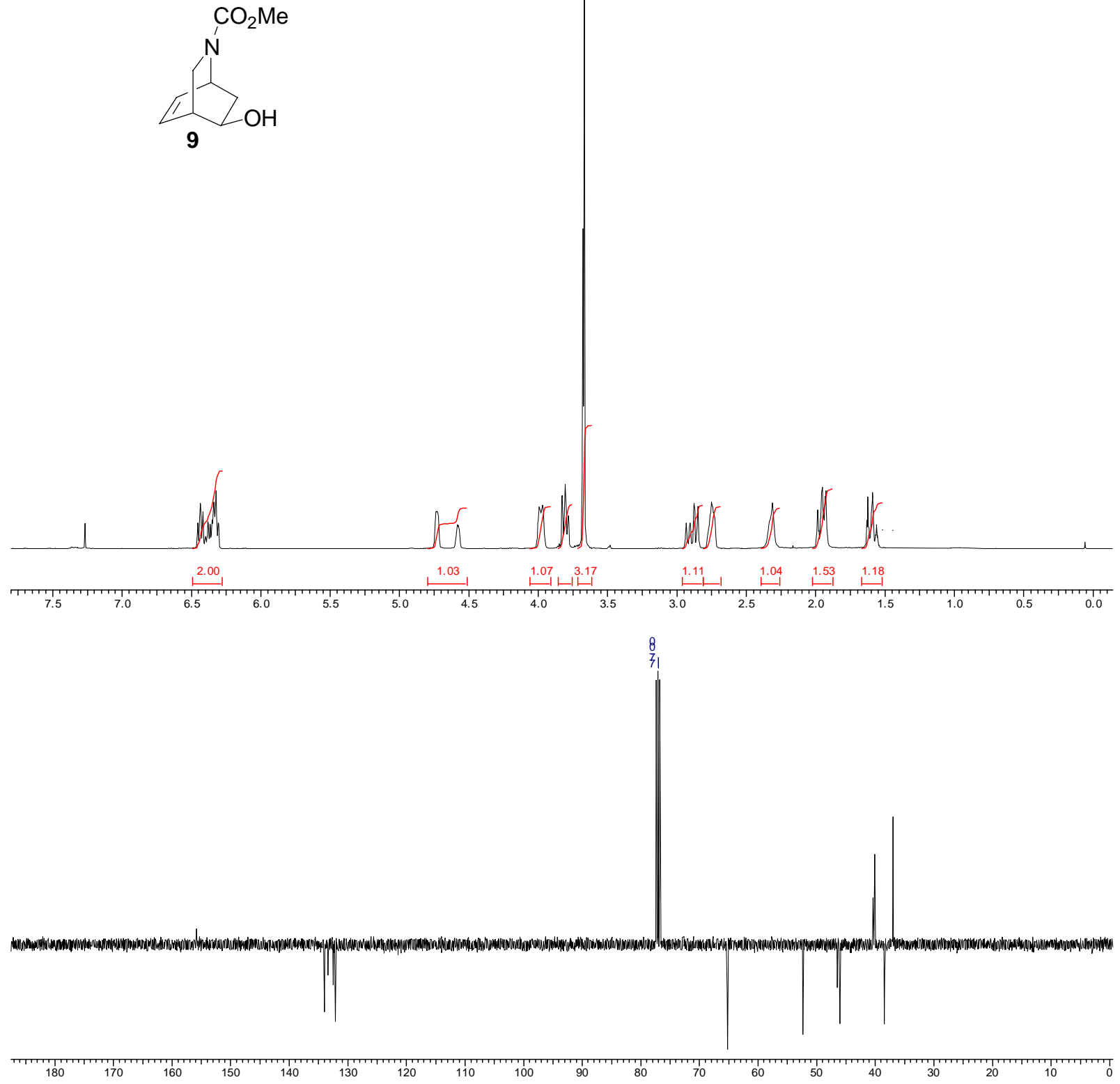
$\mathrm{CO}_{2} \mathrm{Me}$

$\mathrm{N}$
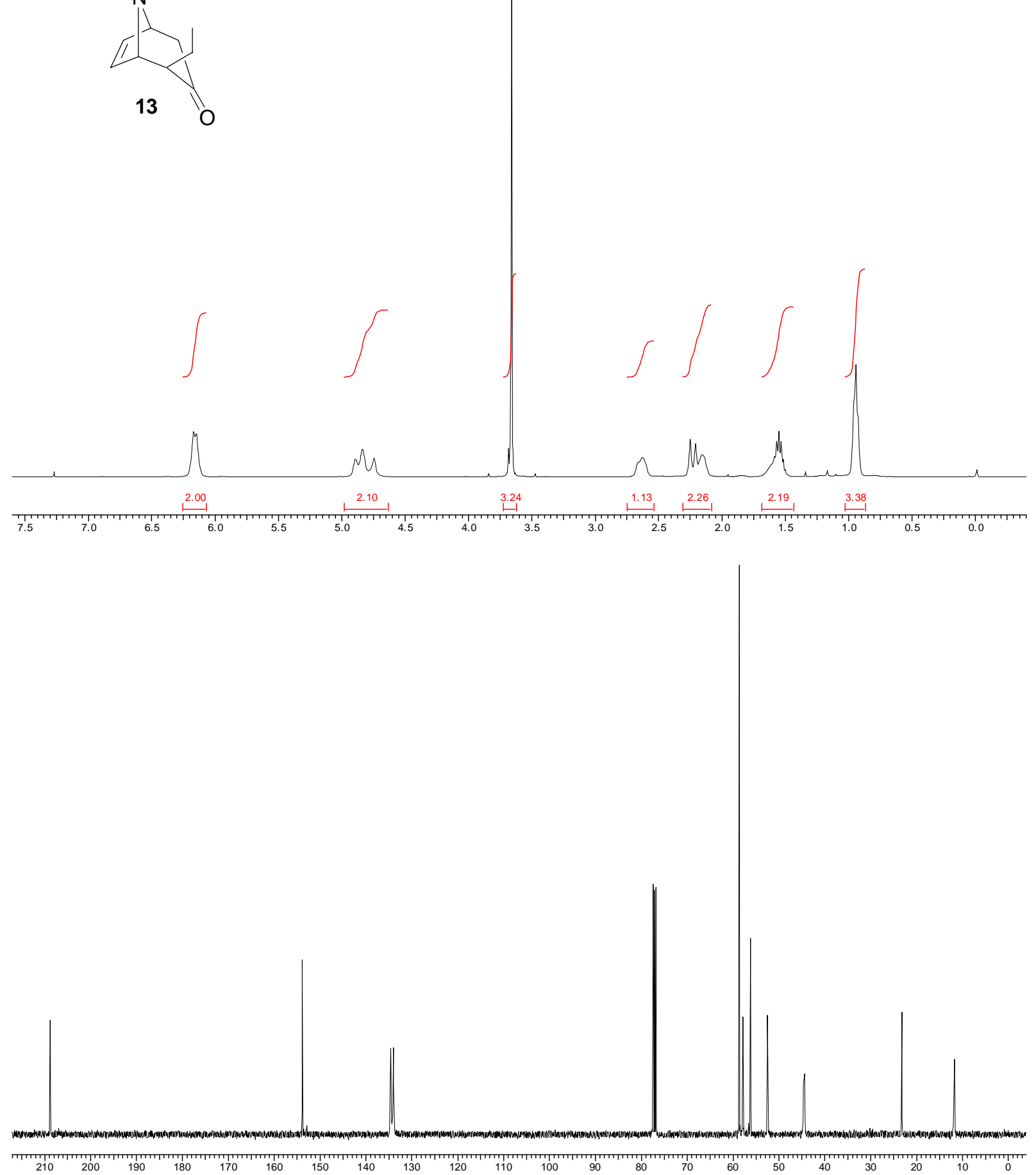


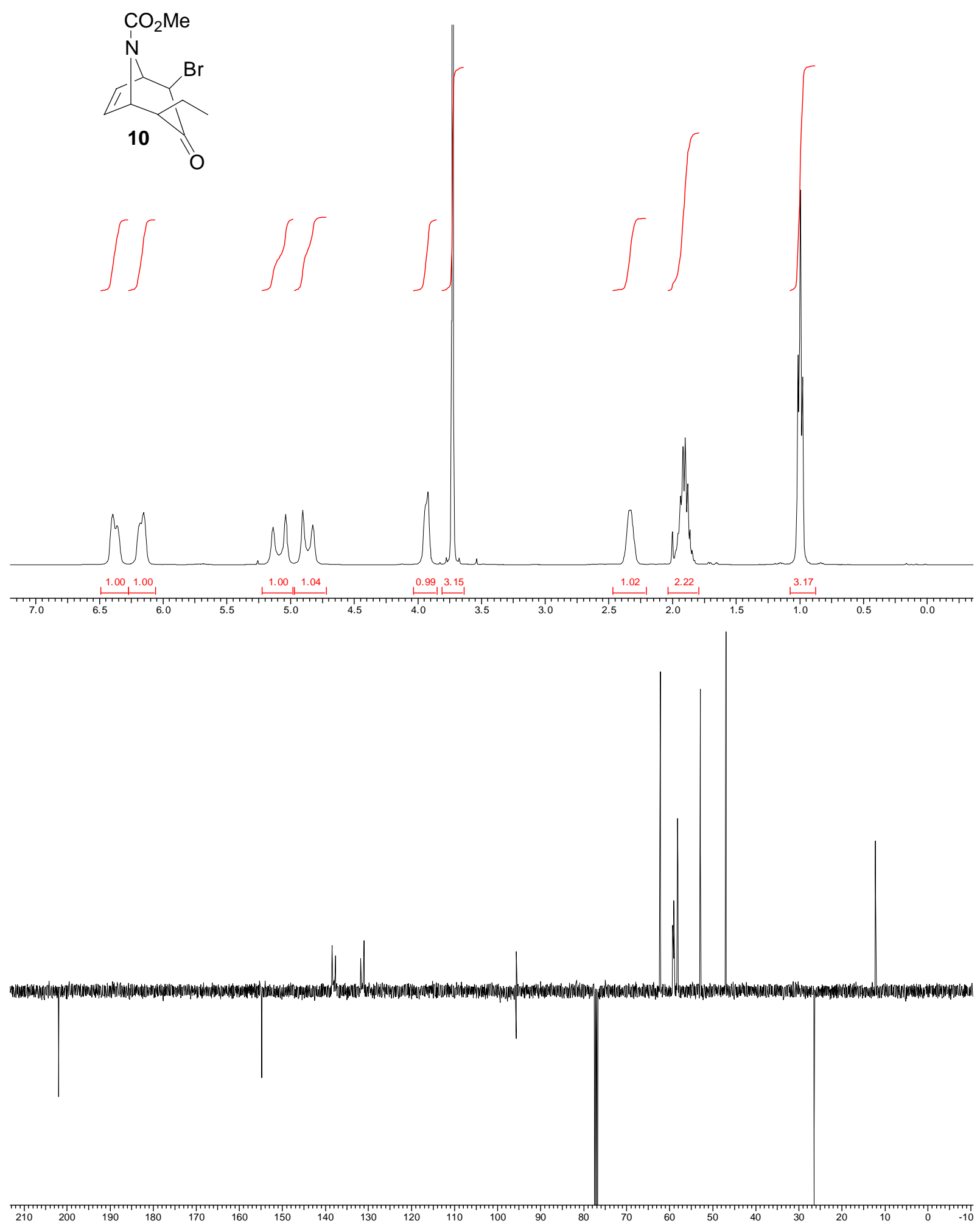



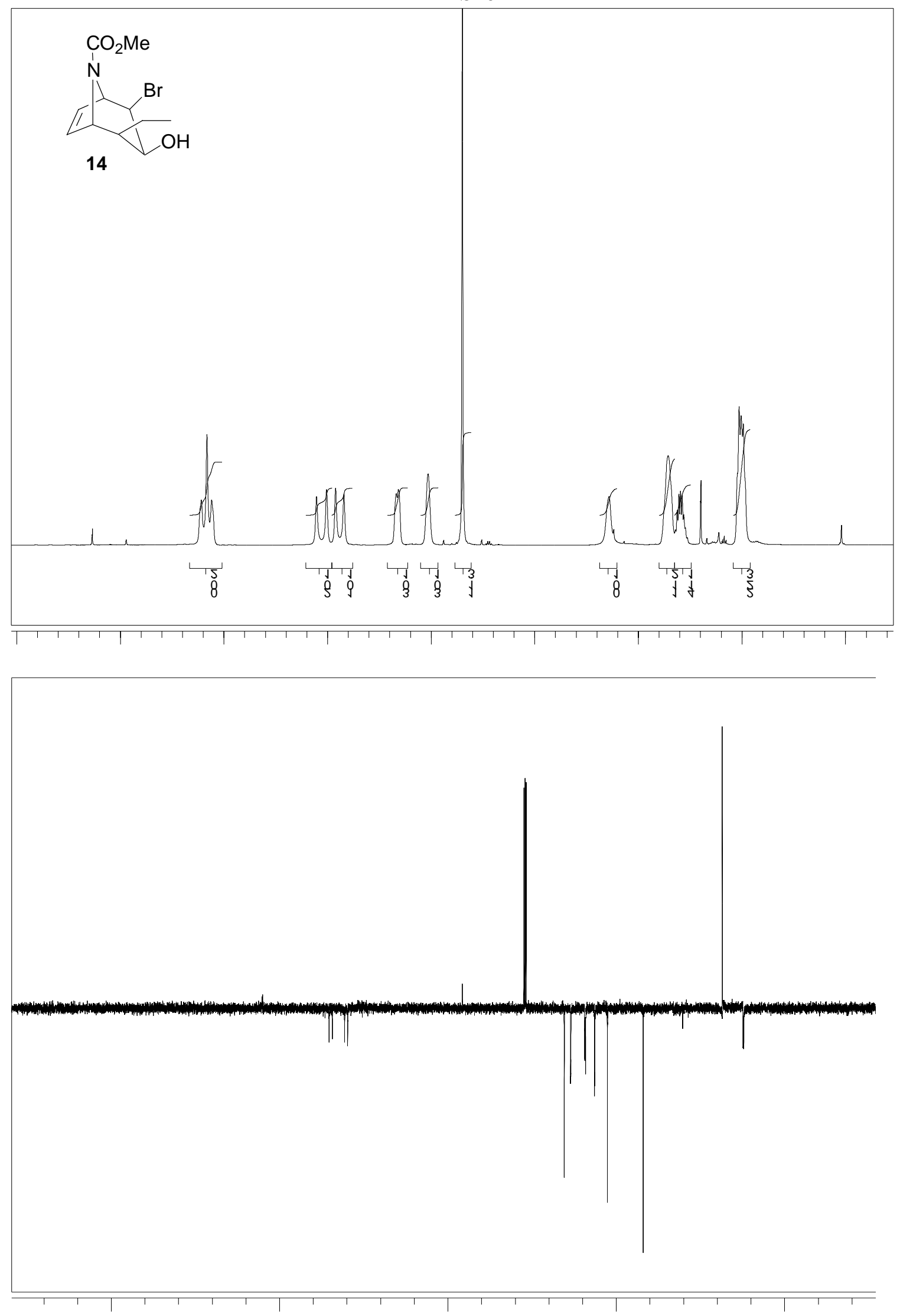

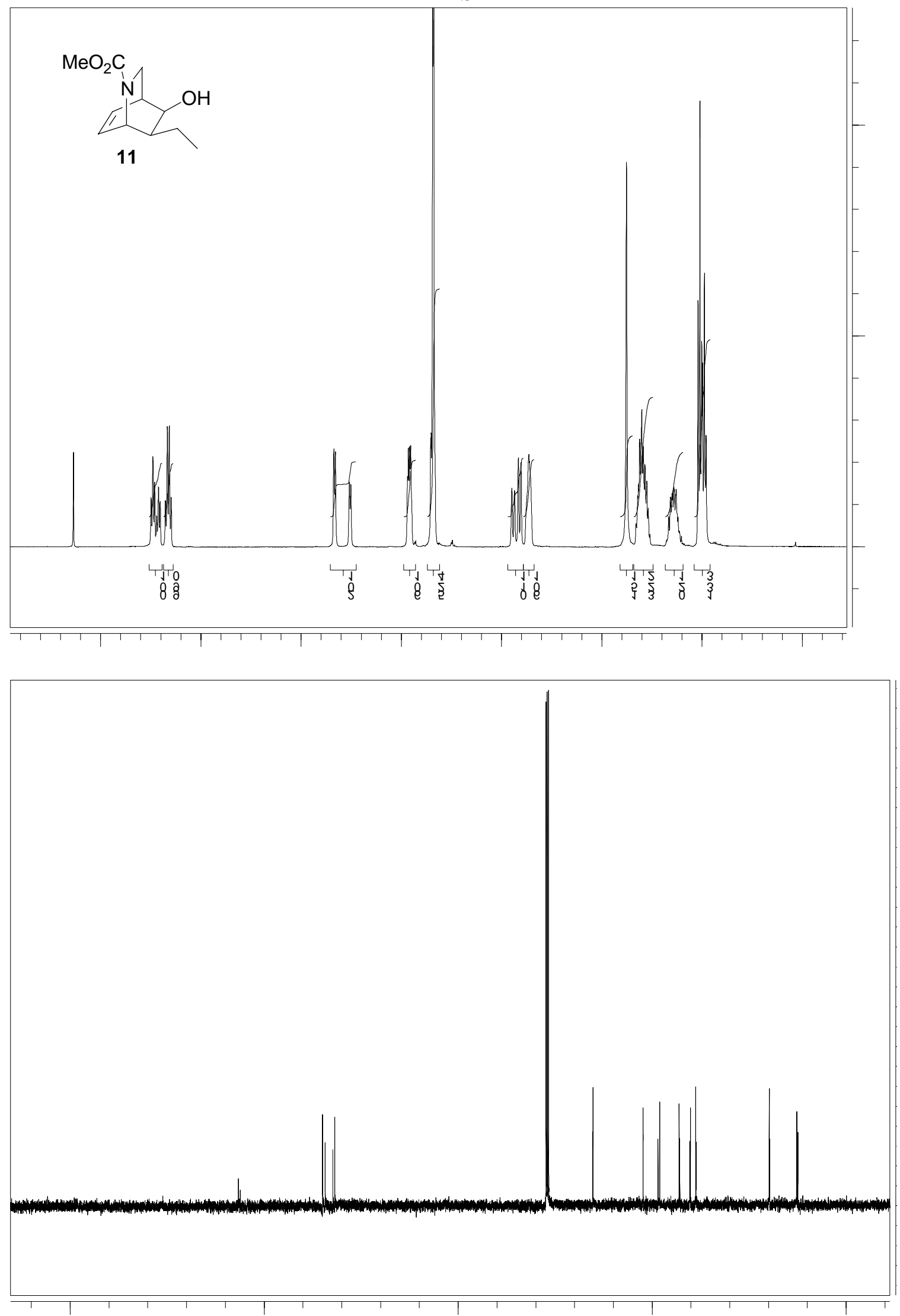

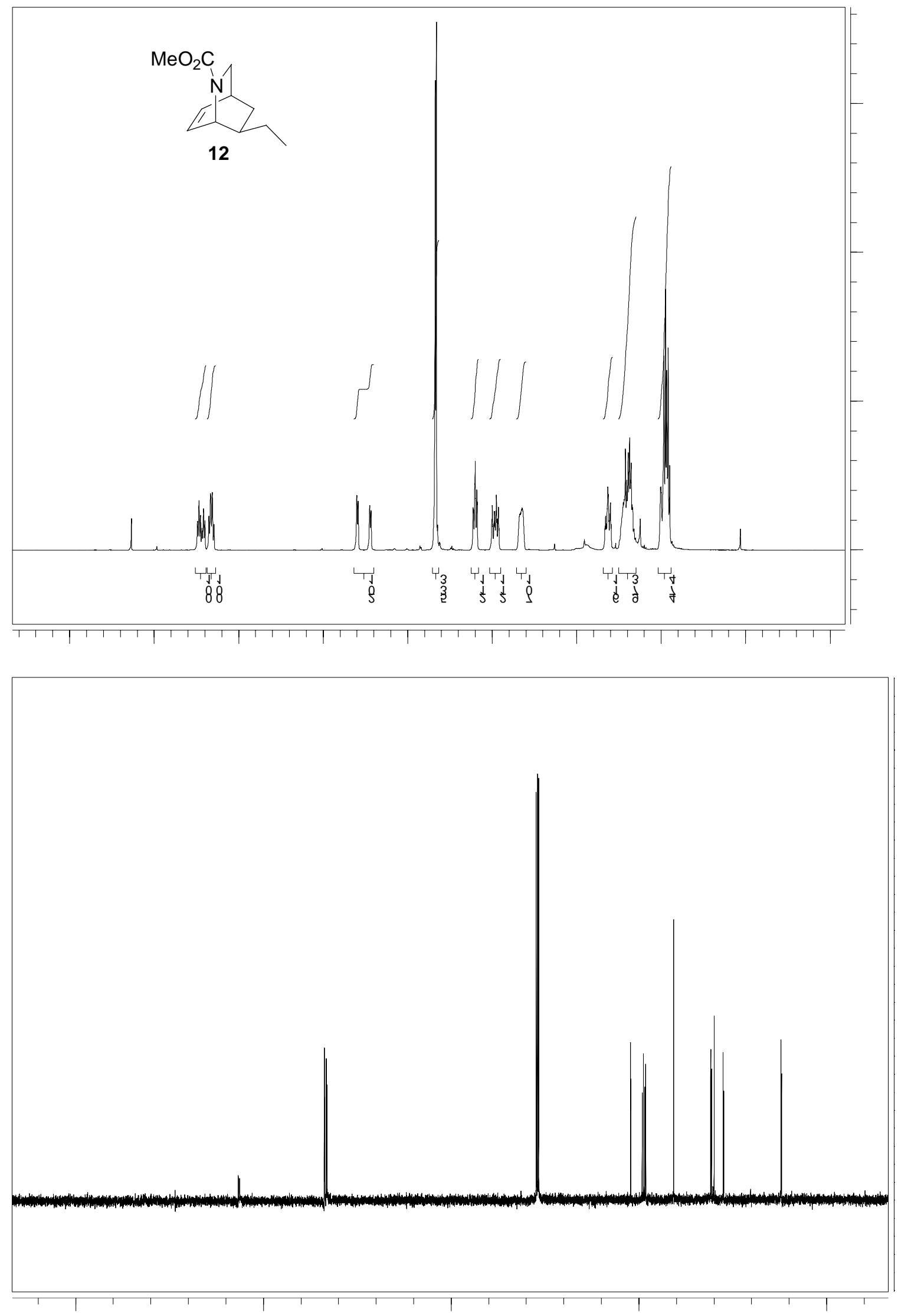

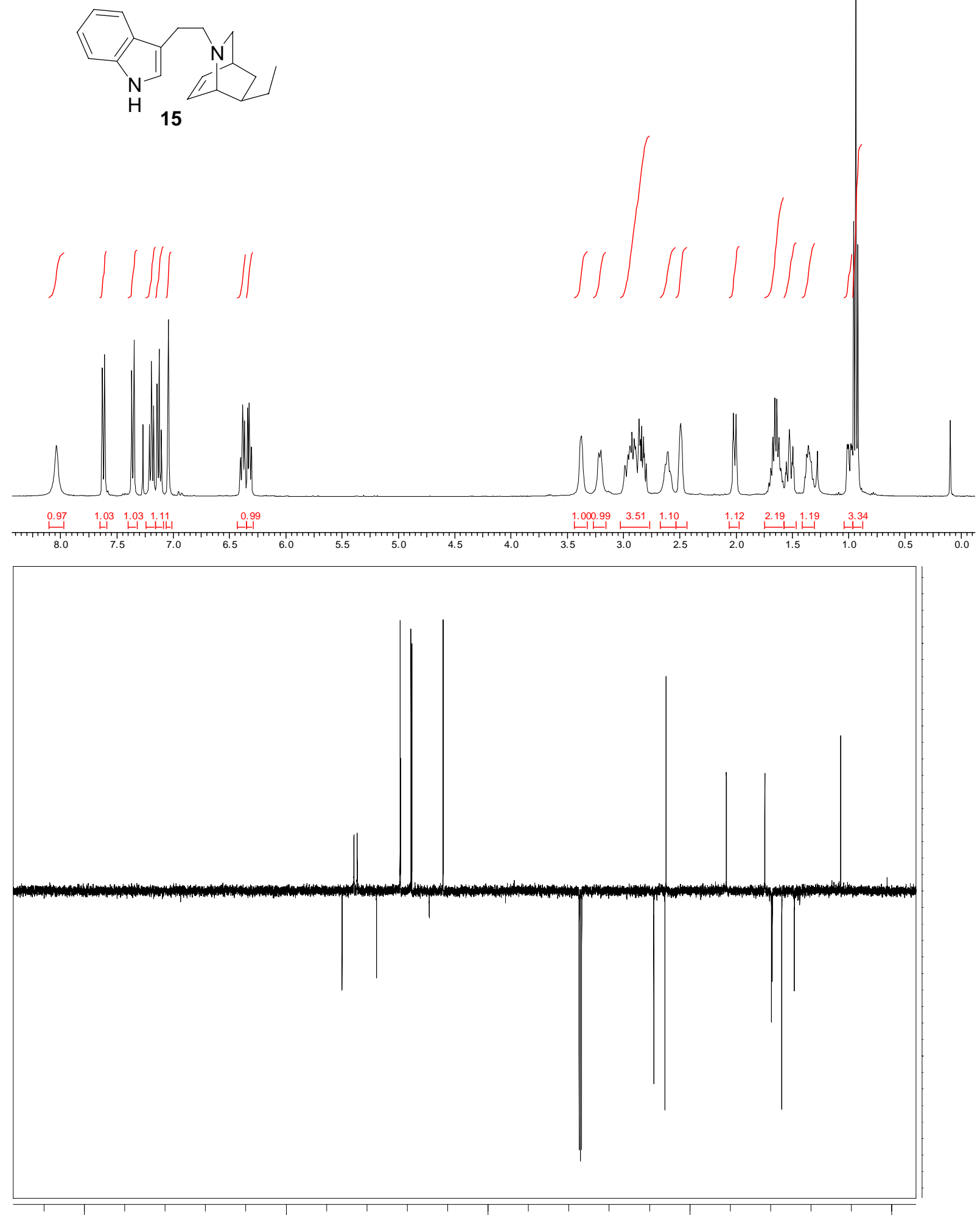

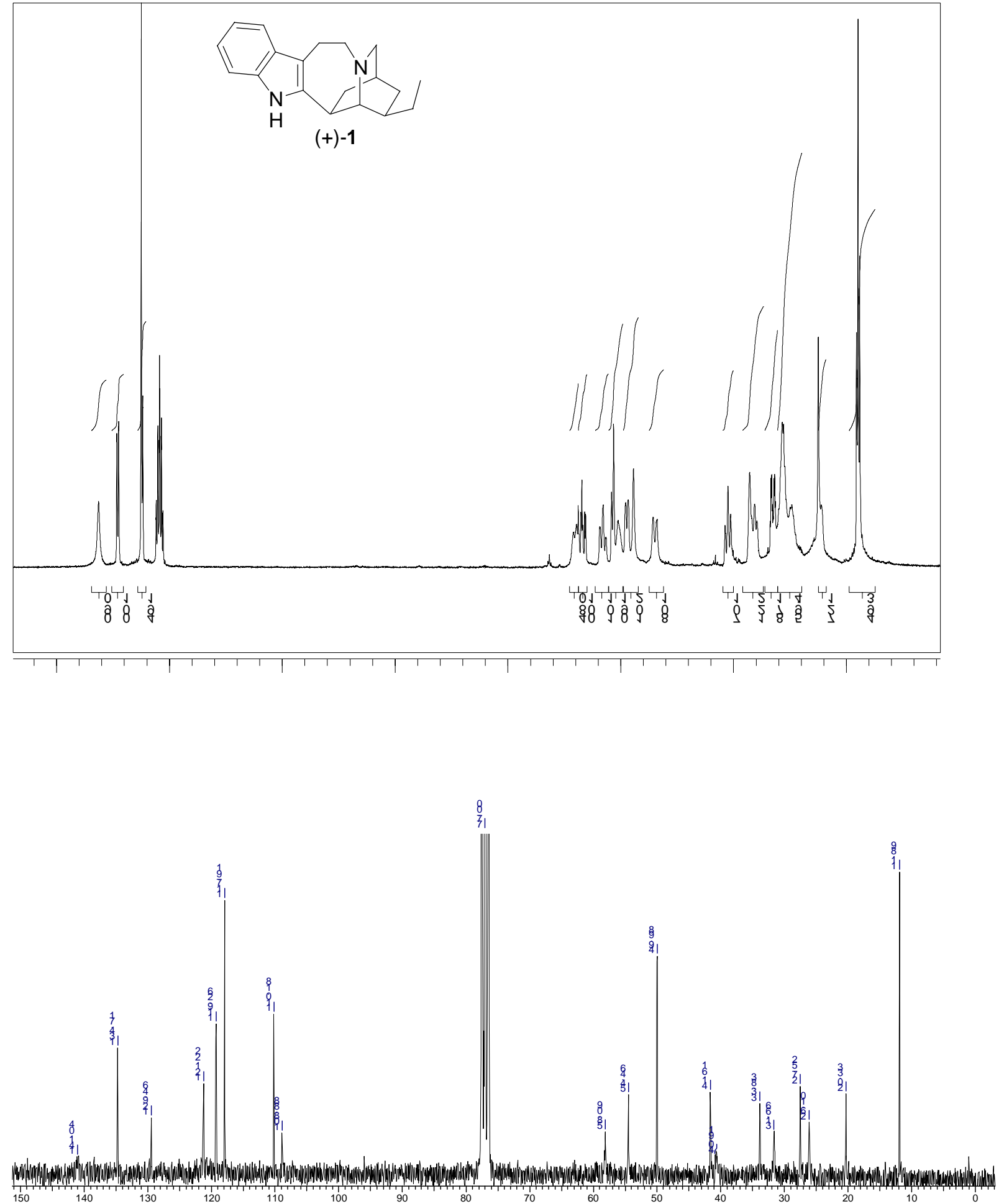